\title{
Nomenclatural changes in the planthopper tribe Hemisphaeriini (Hemiptera: Fulgoromorpha: Issidae), with the description of a new genus and a new species
}

\author{
Rui MENG ${ }^{1}$, Michael Donald WEBB ${ }^{2}$ \& Ying-Lun WANG ${ }^{3, *}$ \\ ${ }^{1,3}$ Key Laboratory of Plant Protection Resources and Pest Management of the Ministry of Education \\ and Entomological Museum, Northwest A\&F University, Yangling, Shaanxi 712100, China. \\ ${ }^{2}$ The Natural History Museum, Cromwell Road, Kensington, London SW7 5BD, London, UK. \\ "Corresponding autor: yinglunw@nwsuaf.edu.cn \\ ${ }^{1}$ Email: mengrui@,nwsuaf.edu.cn \\ ${ }^{2}$ Email: m.webb@nhm.ac.uk \\ ${ }^{1}$ urn:Isid:zoobank.org:author:AB10C4C0-C7EE-42CF-BEC3-3022BCBA0B6D
${ }^{2} \underline{\text { urn: } 1 \text { Isid:zoobank.org:author:FAAE82E2-3C2A-4900-84FE-55CEAD630384 }}$
${ }^{3}$ urn:1sid:zoobank.org:author:D9647615-E0BA-4556-87D6-7C49E651551C
}

Abstract. Nomenclatural changes are made in three previously described genera in the planthopper tribe Hemisphaeriini (Hemiptera: Fulgoromorpha: Issidae: Issinae), viz Gergithus Stål, 1870, Mongoliana Distant, 1909 and Hemisphaeroides Melichar, 1903. In addition, a new genus, Gnezdilovius gen. nov., with Gergithus lineatus Kato, 1933 as its type species, is described for 40 species formerly included in Gergithus, and the generic characteristics of the latter genus is revised. One new species, Gergithus frontilongus sp. nov. from China (Yunnan), is described and illustrated. One additional Gergithus species, previously misidentified as G. signatifrons Melichar, 1906 from Siberut Island, is mentioned and illustrated. Gergithus contusus Walker, 1851 is transferred to Mongoliana and Hemisphaerius atromaculatus Distant, 1916 and H. fuscoclypeatus Distant, 1916 are transferred to Hemisphaeroides. Checklists for all four genera are provided detailing the nomenclatural changes and a key to the 19 genera of Hemisphaeriini is provided. Morphological diversity and distribution of the genera are briefly discussed.

Key words. Fulgoroidea, morphology, new combination, taxonomy.

Meng R., Webb M.D. \& Wang Y.L. 2017. Nomenclatural changes in the planthopper tribe Hemisphaeriini (Hemiptera: Fulgoromorpha: Issidae), with the description of a new genus and a new species. European Journal of Taxonomy 298: 1-25. https://doi.org/10.5852/ejt.2017.298

\section{Introduction}

The planthopper tribe Hemisphaeriini Melichar, 1906 was originally treated as the subfamily Hemisphaeriinae in the family Issidae Spinola, 1839, but was downgraded to a tribe of Issinae by Gnezdilov (2003). Representatives of the tribe occur throughout the Oriental region, marginally 
advancing into the Eastern Palaearctic region (Japan, Korea) and the Australian region (New Guinea) (Gnezdilov 2013c).

Hemisphaeriini take their name from their hemispherical body with the tegmen convex, but can also be distinguished by the indistinct venation of the tegmen and the hind wing being either single-lobed or rudimentary. Members of the tribe seem to imitate beetles, in particular ladybirds (Butler 1875; Gnezdilov 2013a). Initially, eight genera were included in the tribe Hemisphaeriini (Melichar 1906), but after over a century of research, the group is considered to be the second largest issid tribe with currently 18 genera and 176 species.

The present study has revealed several misplaced species in three genera (Gergithus Stål, 1870, Mongoliana Distant, 1909 and Hemisphaeroides Melichar, 1903) and for several of those species described in Gergithus a new genus is described. A new species of Gergithus is also described. In addition, we give a key to all the genera of Hemisphaeriini. This key, together with the diagnoses for each genus, focuses mainly on external characters, as further studies are needed on the large number of genera requiring revision, with details of genitalia, in the future. Similarly, species recognition in the tribe, at present, is based mainly on colour pattern, which is distinct for all species so far studied. Although we redescribe Gergithus, it is not our intention to revise this genus at the present time, as this would require a much larger study, which it outside the scope of this paper. Instead, we provide a checklist to the species of this and three other studied genera with nomenclatural changes indicated. We also briefly discuss the distribution of the four studied genera, updating current information given for the tribe as a whole (Gnezdilov 2013c).

\section{Material and methods}

External morphology was observed under a Leica MZ 125 microscope. All measurements were in millimeters (mm). Morphological terminology follows Gnezdilov et al. (2014b), except that tegmen venation patterns follow Bourgoin et al. (2014). The genital segments of the examined specimens were dissected and macerated in hot $10 \% \mathrm{NaOH}$ solution for about 3 minutes, and subsequently transferred into glycerin. Photographs of the specimens were made using a Leica M205A microscope with a Leica DFC Camera. Images were produced using the software LAS (Leica Application Suite) v. 3.7.

Material examined is deposited in the institutions abbreviated in the text as follows:

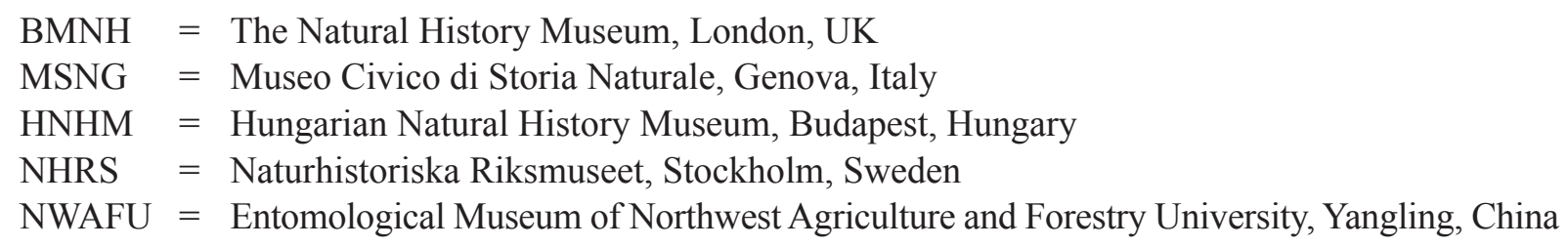

\section{Results}

\section{Key to genera of Hemisphaeriini}

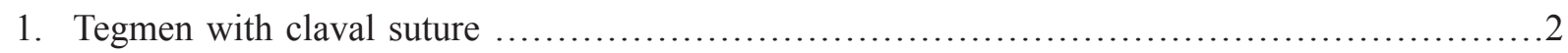

- Tegmen without claval suture .............................................................

2. Tegmen with claval suture distinct in basal $1 / 4$ of wing; metope with median carina rudimentary in its apical part (Genezdilov 2015: figs 1-3) Bruneastrum Gnezdilov, 2015

- Tegmen with claval suture well-developed; metope with complete median carina or median carina absent 
MENG R. et al., Nomenclatorial changes in the planthopper tribe Hemisphaeriini

3. Metope elongate, with median carina, without tubercules (Chen et al. 2014: figs 2-35, 2-36) .Neohemisphaerius Chen, Zhang \& Chang, 2014

- Metope almost as wide as long in middle line, without median carina, with a row of tubercules along lateral margin (Chen et al. 2014: fig. 2-33) Paramongoliana Chen, Zhang \& Chang, 2014

4. Metope with large bulge at center (Genezdilov 2013b: figs 2-4) ...Bolbosphaerius Gnezdilov, 2013

- Metope flat or slightly elevated in median area, without such bulge (Figs 1B, D, F-G, J, L, 2C, 8B, 9D, $10 \mathrm{H})$.....

5. Tegmen depressed at base, costal margin moderately convex at basal one third as "relief shoulder"

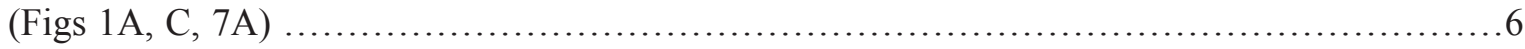

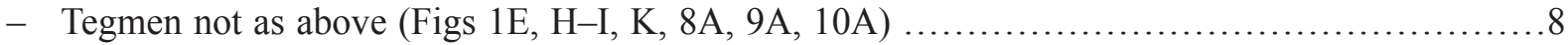

6. Coryphe almost as wide as long, anteclypeus angularly rounded (Fig. 6A-B) ...Gergithus Stål, 1870

- Coryphe distinctly longer than wide, anteclypeus flat (Fig. 1A-D) ..........................

7. Pronotum with median carina; anterior margin not foliate and elevated (Fig. 1C). Metatibiotarsal formula $6-8-2$

.Neogergithoides Sun, Meng \& Wang, 2012

- Pronotum without median carina; anterior margin foliate and elevated (Fig. 1A). Metatibiotarsal formula $6-10-2$ Macrodaruma Fennah, 1978

8. Coryphe elongate, more or less triangular (Fig. 1E) ...Choutagus Zhang, Wang \& Che, 2006

- Coryphe broad, quadrangular (Figs 1H-I, K, 8A, 9A, 10A) ...................................

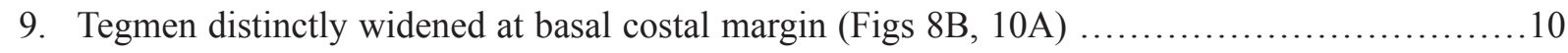

- Tegmen not widened at basal costal margin .............................................11

10. Coryphe 4.5 times as wide as long; metope very broad below eyes (Fig. 10A, D)

Hemisphaeroides Melichar, 1903

- Coryphe 1.5 times as wide as long; metope not very broad below eyes (Fig. 8A-B)

Mongoliana Distant, 1906



- Metope with lateral margin not right-angled at mid-length .................................. 13

12. Mesonotum elevated, length in midline almost equal to combined length of coryphe and pronotum; tegmen distinctly long, oblong (Melichar 1906: fig. 15) ......Hysteropterissus Melichar, 1906

- Mesonotum flat, twice combined length of coryphe and pronotum in mid line; tegmen relatively wide, nearly rhomboidal (Fig. 1K) ....................Rotundiforma Meng, Wang \& Qin, 2013

13. Clypeus with median carina (Melichar 1906: fig. 16) .............Hysterosphaerius Melichar, 1906

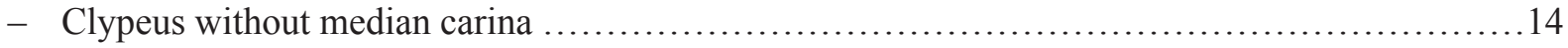

14. Fore and mid femora dilated (Melichar 1906: fig. 14) ...................Hemiphile Metcalf, 1952

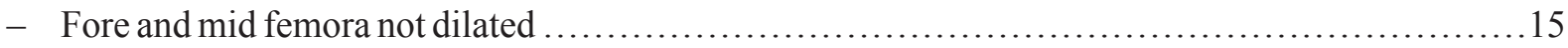

15. Metope with a row of tubercles and median carina (Fig. 1G) ........Gergithoides Schumacher, 1915

- Metope without tubercles and median carina (Figs 1J, 9C-D) ............................. 16

16. Hind wing well-developed, longer than half length of tegmen ...........Gnezdilovius gen. nov.

- Hind wing shorter than half length of tegmen 
17. Aedeagus with two processes, suspensorium indistinct

- Aedeagus without process, suspensorium distinct

Hemisphaerius Schaum, 1850

18. Pygofer in profile with hind margin distinctly angulated; phallobase asymmetrical at apex (Chan \& Yang 1994: figs 27-30)

Euhemisphaerius Chan \& Yang, 1994

- Pygofer not distinctly angulated; phallobase symmetrical (Chan \& Yang 1994: fig. 26)

Epyhemisphaerius Chan \& Yang, 1994
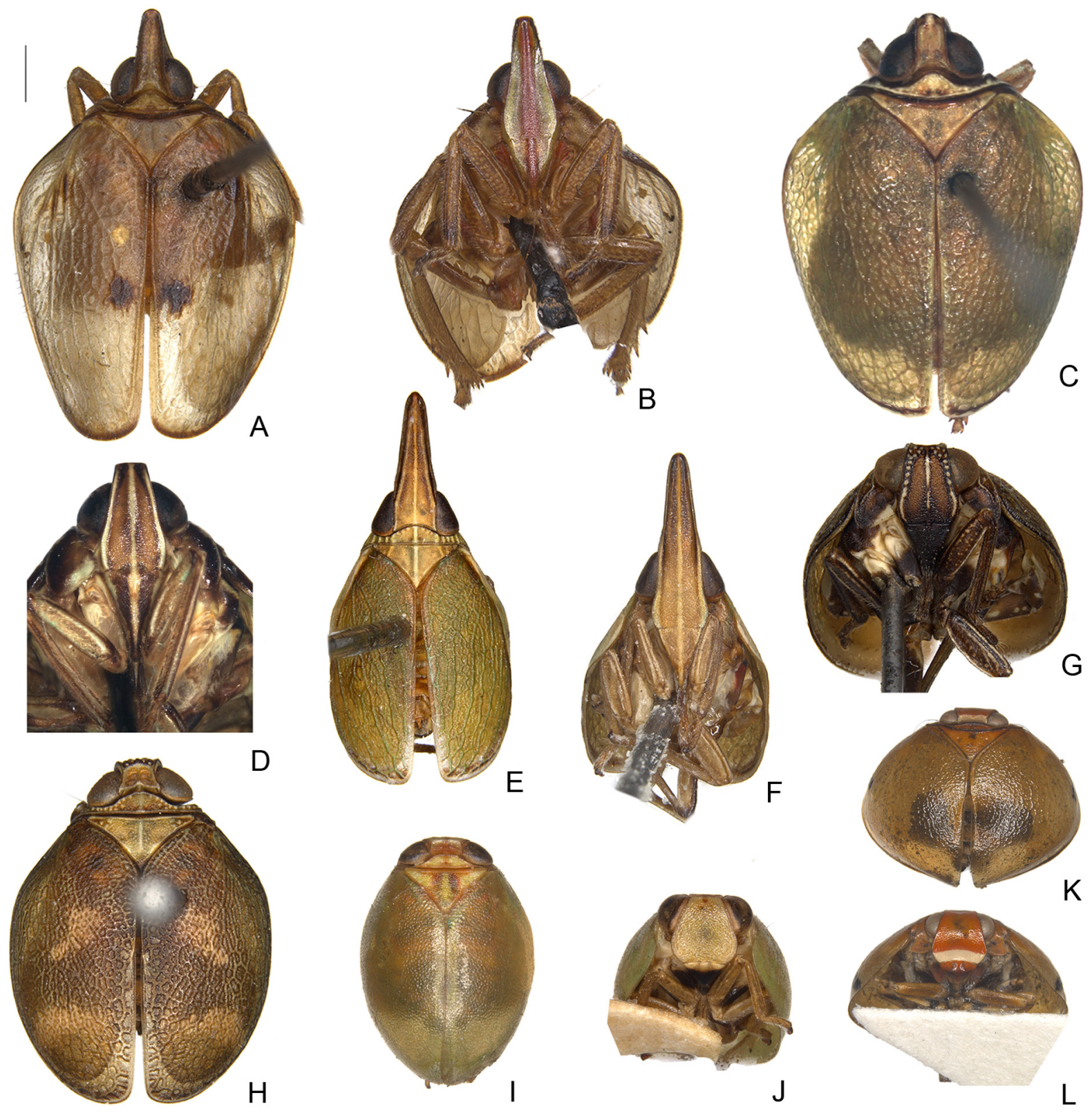

Fig. 1. Hemisphaerini. A-B. Macrodaruma pertinax Fennah, 1978. A. Habitus, dorsal view. B. Habitus, ventral view. - C-D. Neogergithoides tubercularis Sun, Meng \& Wang, 2012. C. Habitus, dorsal view. D. Metope and clypeus, facial view. - E-F. Choutagus longicephalus Zhang, Wang \& Che, 2006. E. Habitus, dorsal view. F. Habitus, ventral view. - G-H. Gergithoides carinatifrons Schumacher, 1915. G. Habitus, ventral view. H. Habitus, dorsal view. - I-J. Hemisphaerius lysanias Fennah, 1978. I. Habitus, dorsal view. J. Metope and clypeus, facial view. - K-L. Rotundiforma nigrimaculata Meng, Wang \& Qin, 2013. K. Habitus, dorsal view. L. Metope and clypeus, facial view. Scale bar $=1 \mathrm{~mm}$. 
MENG R. et al., Nomenclatorial changes in the planthopper tribe Hemisphaeriini

\author{
Class Hexapoda Blainville, 1816 \\ Order Hemiptera Linnaeus, 1758 \\ Infraorder Fulgoromorpha Evans, 1946 \\ Family Issidae Spinola, 1839 \\ Tribe Hemisphaeriini Melichar, 1906
}

Gergithus Stål, 1870

Figs $1-7$

Gergithus Stål, 1870: 756. Type species: Hemispharius schaumi Stål, 1855, by original designation.

\title{
Diagnosis
}

Coryphe subquadrate (Figs 2A, 5A, D, 6A), metope elongate (Figs 2C, 5B, F, 6D, 7C), postclypeus nearly triangular and in same oblique plane with metope, anteclypeus angular (Figs 2D, 5C, E, 6B, 7B) and tegmen with costal margin moderately convex at basal one third as "relief shoulder" (Figs 2A, 5A, 6A, 7A).

\section{Redescription}

Coryphe subquadrate, margins carinate, anterior margin straight or weakly concave, posterior margin weakly concave (Figs 2A, 5A, D, 6C, 7A). Metope greatly elongate, slightly widening below antennae; upper margin straight (Figs 2C, 5B, F, 6D, 7C). Metopoclypeal suture straight (Figs 2C, 5B, F, 6D, 7C). Postclypeus nearly triangular and in same oblique plane, with lateral margins continuous with those of metope; anteclypeus extremely narrow in ventral view, and roundly angulately protruding ventrally in lateral view (Figs 2C-D, 5B-C, E-F, 6B, D, 7B-C). Ocelli rudimentary. Pronotum clearly short, as long as coryphe in middle line or slightly shorter than it, extremely narrow behind eyes, margins obviously ridged; lateral lobes large, fan-shaped in frontal view, ventral margins moderately oblique, lateroventral angles obtusely convex (Figs 2A, C, 5A-B, D, F, 6C-D, 7A, C). Mesonotum with anterior margin obviously ridged and shallowly concave, with two rounded pits medially on each side (Figs 2A, 5A, D, 6C, 7A). Tegula small. Tegmen ovate-oblong, depressed at basal surface, costal margin moderately convex at basal one third as "relief shoulder", longitudinal veins prominent, with many supernumerary branches and numerous irregular transverse veinlets; claval suture absent (Figs 2F, 5C-D, 6E, 7B). Hind wing mostly well-developed single lobe, veins netlike, sometimes reduced (Fig. 2G). Legs moderately long, not dilated; hind tibia with two spines distally.

\section{Distribution}

Sri Lanka, India, Burma, Thailand, China (Yunnan Province), Malaysia, Indonesia.

\section{Remarks}

From a total of 62 species previously included in the genus we transfer several species to a new genus described below and transfer G. contusus (Walker, 1851) to Mongaliana. However, a detailed revision of the latter genus is needed in the future. Twenty two species are retained in Gergithus, most of them after examination of the type (Butler 1875; Distant, 1906, 1916; Walker 1851) or of other specimens in the BMNH. Images of type specimens are provided for: G. schaumi (Stål, 1855) (Fig. 7A-D), G. cribratus Melichar, 1906 (Fig. 5D-F) and G. signatifrons Melichar, 1906 (Fig. 6A-F). The species G. ignotus Melichar, 1906, G. lineolatus Melichar, 1906, G. pigrans Melichar, 1906, G. secundus (Melichar, 1903) and $G$. vidulus Melichar, 1906 are known by their original descriptions only. 


\section{Checklist of species of Gergithus Stål, 1870}

Species in BMNH indicated by *:

* G. bipustulatus (Walker, 1858). As Hemisphaerius bipustulatus Walker, 1858: 95, Sri Lanka

* G. complicatus Distant, 1916. Distant 1916: 103, fig. 77, Sri Lanka

* G. conspicularis Distant, 1916. Distant 1913: 103, Sri Lanka

* G. cribratus Melichar, 1906. Melichar 1906: 64, Sri Lanka (Fig. 5D-F)

* G. dubius (Butler, 1875). As Hemisphaerius dubius Butler, 1875: 97, pl. IV, fig. 17, Sri Lanka

* G. elongates (Distant, 1906). As Hemisphaerius elongatus Distant, 1906: 362, India

* G. erebus Distant, 1916. Distant 1916: 101, fig. 76, India

G. frontilongus sp. nov., China (Yunnan) (Figs 2-4)

* G. herbaceous (Kirby, 1891). As Hemisphaerius herbaceous Kirby, 1891: 147, Sri Lanka

G. ignotus Melichar, 1906. Melichar 1906: 66, Burma

G. lineolatus Melichar, 1906. Melichar 1906: 60, Sumatra

* G. niger (Walker, 1857). As Hemisphaerius niger Walker, 1857: 155, Indonesia, Malaysia, Thailand As Hemisphaerius walkeri Butler, 1875: 100, replacement name for Hemisphaerius chilocoroides Walker, 1862: 308. Synomized by Liang (2001)

* G. nilgiriensis (Distant, 1906) As Hemisphaerius nilgiriensis Distant, 1906: 361, India

G. pigrans Melichar, 1906. Distant 1906: 64, Indonesia (Kei Island)

* G. proteus Distant, 1916. Distant 1916: 102, India

* G. reticulatus (Distant, 1906). As Hemisphaerius reticulatus Distant, 1906: 361, India

* G. schaumi (Stål, 1855). As Hemisphaerius schaumi Stål,1855: 191, Sri Lanka (Fig. 7A-D)

G. secundus (Melichar, 1903). As Hemisphaerius secundus Melichar, 1903: 75, Sri Lanka

G. signatifrons Melichar, 1906. Melichar 1906: 60, Indonesia (Sumatra) (Fig. 6A-F)

* G. venosus (Distant, 1906). As Hemisphaerius venosus Distant, 1906: 363, India

* G. versicolor Distant, 1916. Distant 1916: 102, Sri Lanka

G. vidulus Melichar, 1906. Melichar 1906: 62, India

Gergithus frontilongus sp. nov. urn:1sid:zoobank.org:act:4C95A579-8E80-4E3B-B79D-3D9B02DAE36E

Figs $2-4,7 \mathrm{E}-\mathrm{F}$

\section{Diagnosis}

This new species can be distinguished from other congeners by its distinct colouration (see description). In general coloration it comes closest to G. complicatus, but can be distinguished by: 1) coryphe flavous with two black spots (in G. complicatus, coryphe ochreous with four castaneous spots); 2) metope and clypeus not concolorous, metope with red central fascia, clypeus with flavous central fascia (in G. complicatus, metope and clypeus concolorous, central fascia ochreous).

\section{Etymology}

The specific epithet is constituted from the Latin words "frons-" and "longus", referring to the elongate metope.

\section{Material examined}

\section{Holotype}

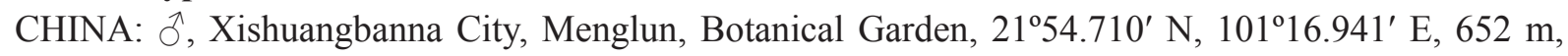
16 Nov. 2009, Guo Tang and Zhiyuan Yao leg. (NWAFU). 

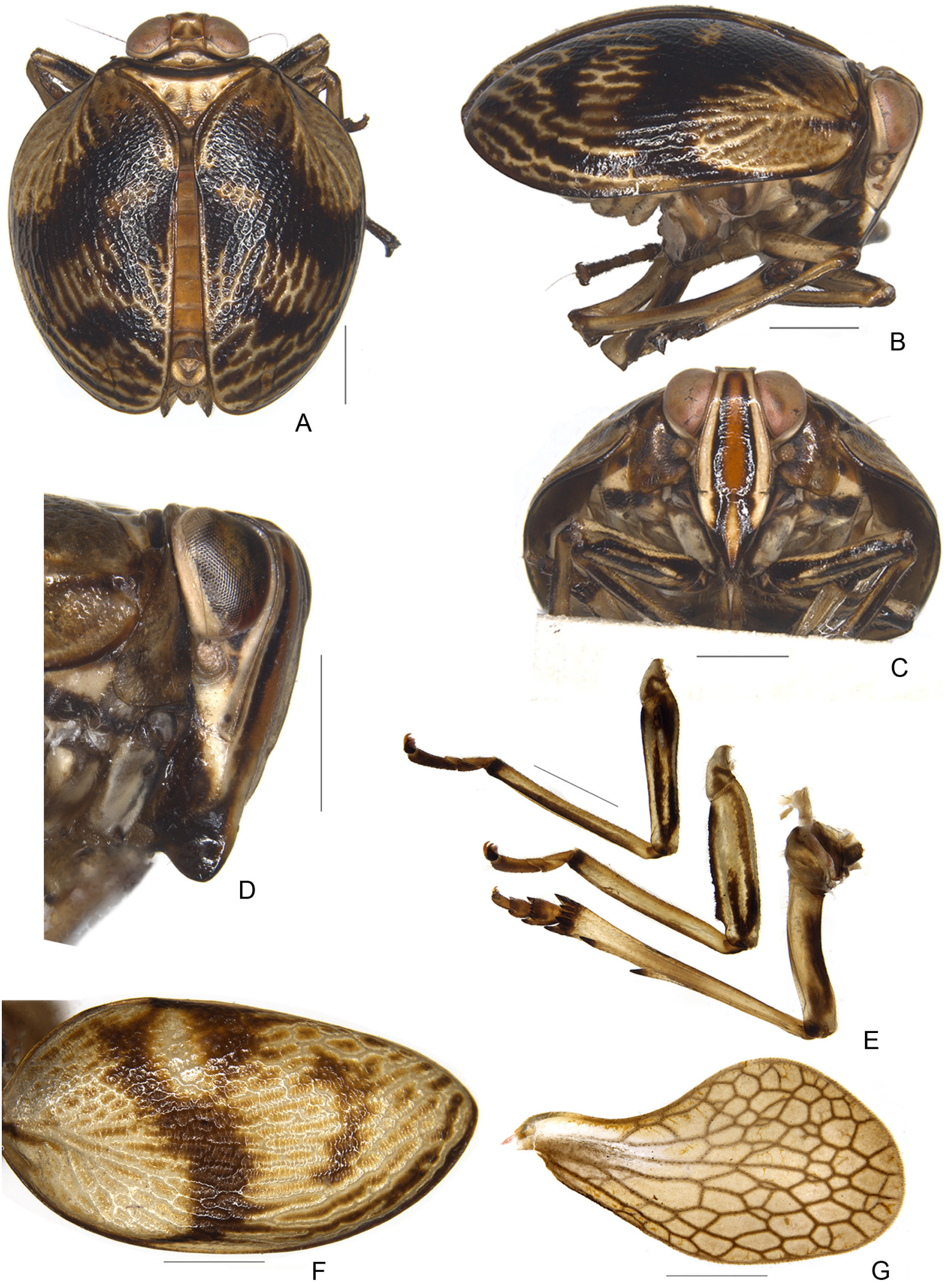

C
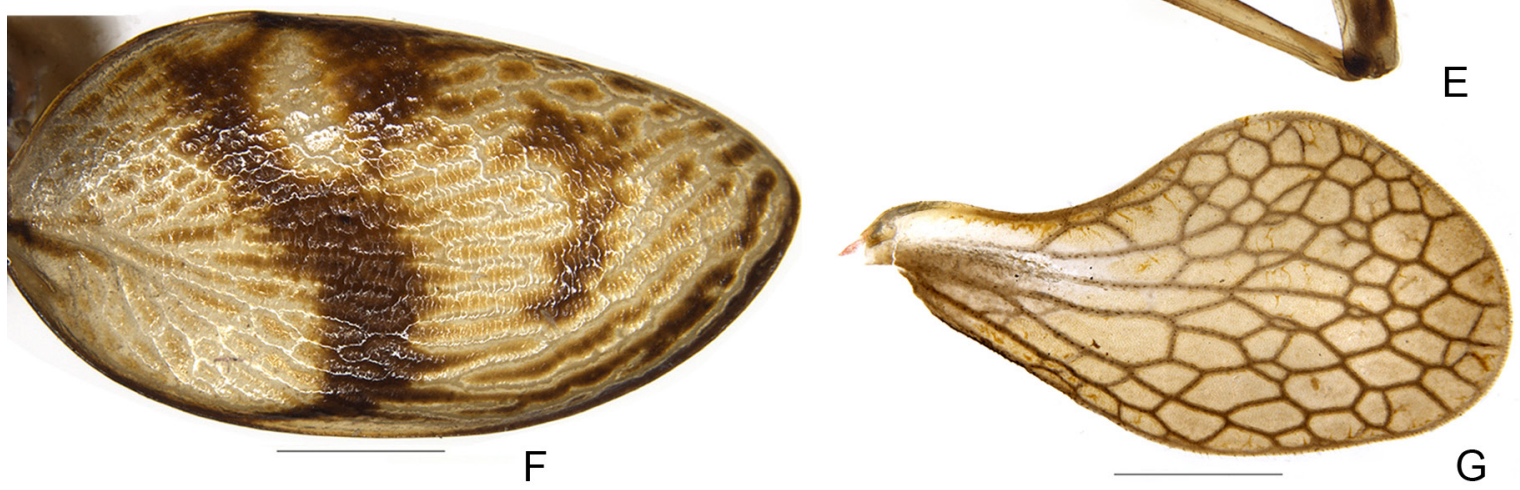

Fig. 2. Gergithus frontilongus sp. nov. A. Habitus, dorsal view. B. Habitus, lateral view. C. Metope and clypeus, facial view. D. Metope and clypeus, lateral view. E. Fore leg, mid leg, hind leg. F. Tegmen. G. Hind wing. Scale bars $=1 \mathrm{~mm}$. 


\section{Paratypes}

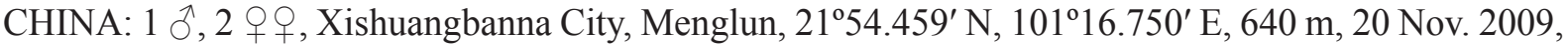
Guo Tang and Zhiyuan Yao leg.; 1 ऽ, Xishuangbanna City, Menglun, Botanical Garden, 21 ${ }^{\circ} 54.05^{\prime}$ N,

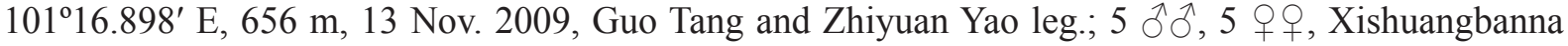
City, Menglun, Botanical Garden, $21^{\circ} 54.617^{\prime}$ N, 101 ${ }^{\circ} 16.843^{\prime}$ E, $738 \pm 17$ m, 8 Aug. 2011, Guo Zheng leg., collected by canopy fogging (all in NWAFU, 1 त and 1 क collected by Guo Zheng in BMNH).

\section{Description}

Measurements. Male length $(\mathrm{N}=8)$ (including tegmen): $4.8-5.5 \mathrm{~mm}$, length of tegmen: 3.9-4.6 mm; female length $(\mathrm{N}=7)$ (including tegmen): 5.1-5.6 mm, length of tegmen: $4.1-4.6 \mathrm{~mm}$.

Colouration. Body alternating luteotestaceous and black, with large black irregular maculations. Coryphe yellow, with two black speckles. Metope flavescent on both sides, with two lateral black fasciae and central red fascia. Gena flavescent with fuscous speckle. Clypeus with postclypeus same color pattern as metope, but central fascia fulvous, anteclypeus black. Eyes pale red or rufous. Pronotum yellow with fuscous speckles in middle, lateral lobes dark brown. Mesonotum flavous, with median carina, central pits and tip fuscous. Tegmen with wide fuscous fascia from basal one third of costal margin to posterior margin, connected with large subtriangulate fuscous macula after fascia and enclosing pale yellow spot, relatively short and narrow fuscous fascia near distal one third, with series of irregular infuscate speckles at gaps of pale veins. Hind wing pale brown, veins fuscous. Legs fulvous with black stripes, tips of teeth black. Abdomen fulvous (Fig. 2A-G).

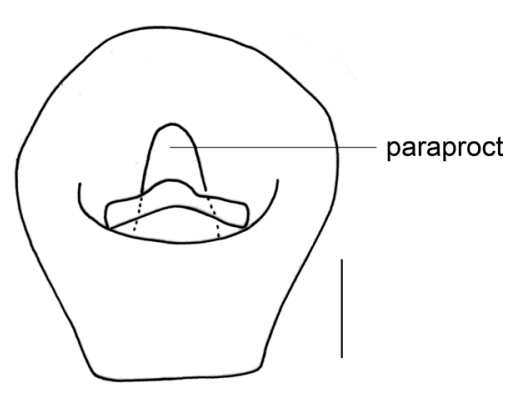

A
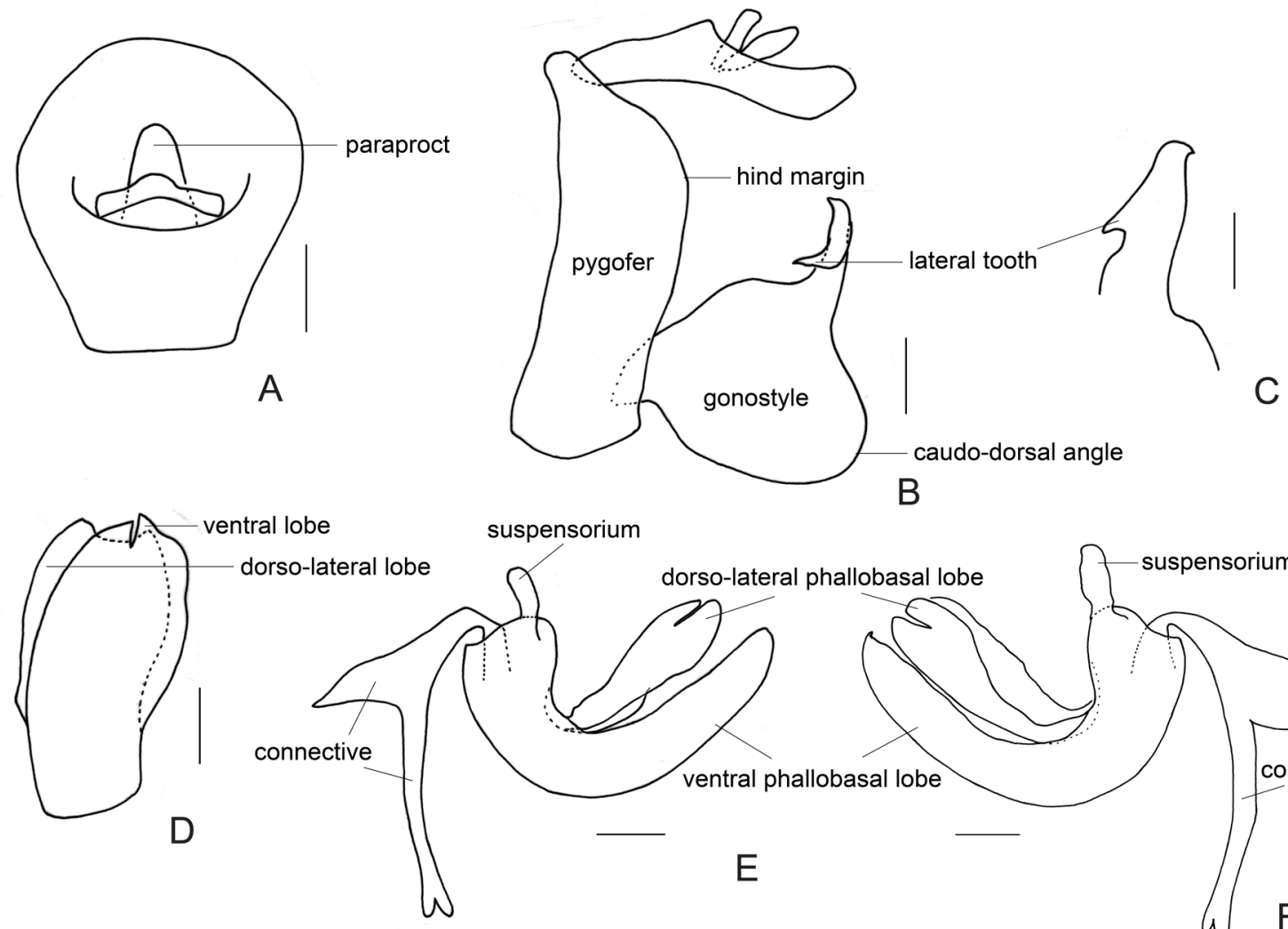

suspensorium

B

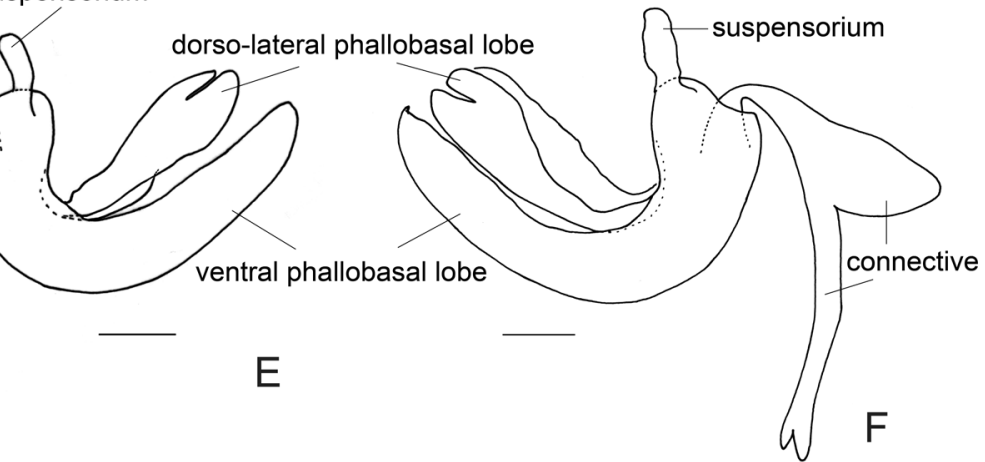

Fig. 3. Gergithus frontilongus sp. nov. A. Male anal tube, dorsal view. B. Male genitalia, lateral view. C. Capitulum of gonostyle, dorsal view. D. Phallobase, ventral view. E. Penis, left view. F. Penis, right view. Scale bars $=0.2 \mathrm{~mm}$. 
MENG R. et al., Nomenclatorial changes in the planthopper tribe Hemisphaeriini

Head And thorax. Coryphe 1.3 times as wide between basal angles as median length, median carina present (Fig. 2A). Metope about 3.5 times as long in middle as width at upper margin, 2.0 times as wide at widest part below antennae as at narrowest upper margin (Fig. 2C). Mesonotum large, 2.6 times as long as pronotum in midline, approximately 2.5 times as wide at anterior margin as long in midline, median carina weak (Fig. 2A). Tegmen ovate-oblong, approximately 2.0 times as long in midline as wide at widest part; costal margin moderately convex at basal one third, apical margin acutely rounded, postclaval margin straight; postcostal cell very wide, basal cell moderately long; longitudinal veins distinctly multiramose throughout wing, with transverse veins more dense in basal third of wing (Fig. 2F). Hind wing veins net-like (Fig. 2G). Legs with fore femora roundly convex at apex, mid femora deeply concave subapically and roundly convex apically (Fig. 2E). Metatibiotarsal formula 6-11-2 (Fig. 2G).

Male genitalia. Anal tube nearly ovate in dorsal view, slightly longer than wide in midline, narrow at base, gradually widening to middle, semicircular at distal half, apical margin rounded (Fig. 3A). Paraproct digitate, 0.4 times as long as anal tube (Fig. 3A). Pygofer narrow, hind margin slightly roundly produced near dorsal margin (Fig. 3B). Dorso-lateral phallobasal lobes asymmetrical, distal part membranous, and furcated into two lobes laterally, obtusely concave dorsally; ventral phallobasal lobe large, longer than dorsolateral phallobasal lobe, right side clearly wider than left side in ventral view, apical part membranous and in form of two lobes, lobes pointed apically. Aedeagus without ventral hooks (Fig. 3D-F). Gonostyle stout, hind margin emarginate medially, anterior margin moderately convex at middle, caudo-dorsal angle rounded (Fig. 3B); capitulum of style long and thin, with a large lateral tooth and a small sharp apical process (Fig. 3C).

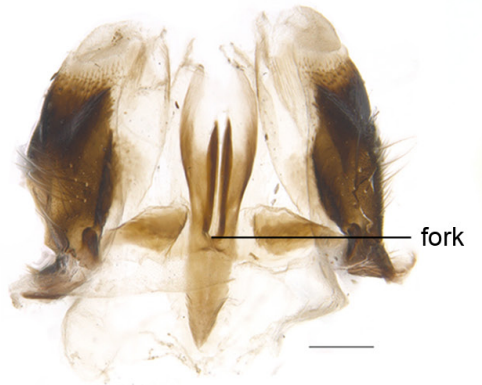

A

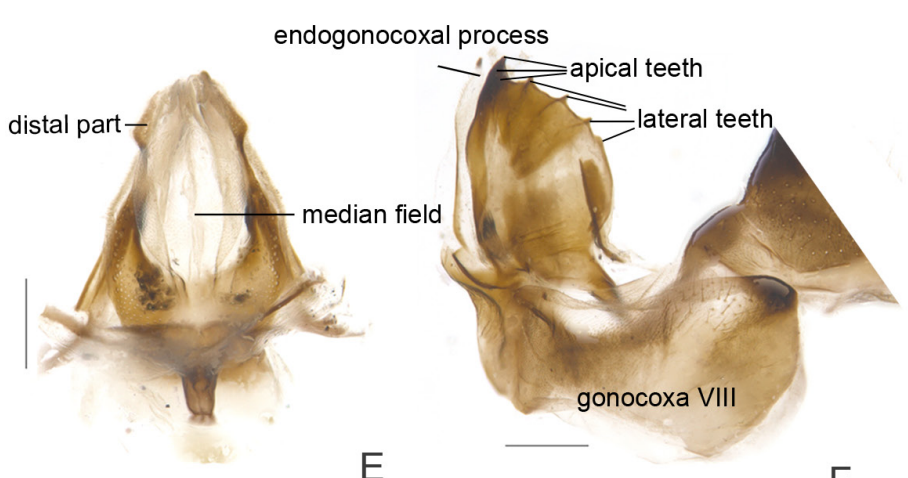

$\mathrm{F}$

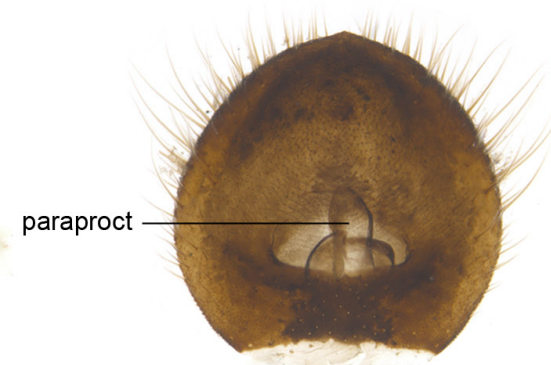

C

B

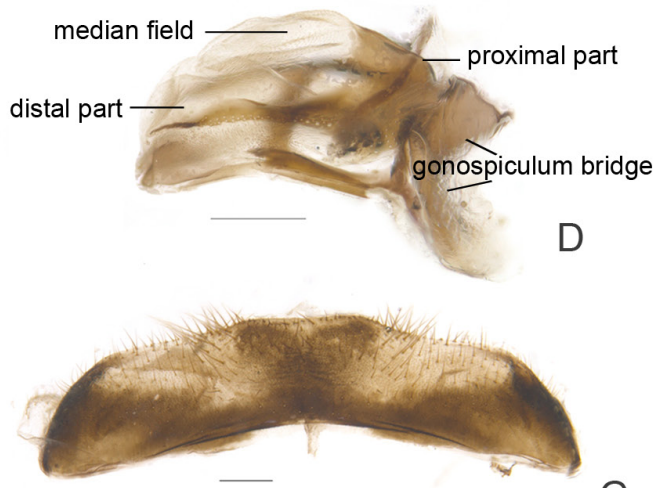

G

Fig. 4. Gergithus frontilongus sp. nov. A. Gonoplac, dorsal view. B. Gonoplac, right view. C. Female anal tube, dorsal view. D. Gonapophysis IX and gonaspiculum bridge, right view. E. Gonapophysis IX and gonaspiculum bridge, dorsal view. F. Gonocoxa VIII and gonapophysis VIII, right view. G. Sternum VII, ventral view. Scale bars $=0.2 \mathrm{~mm}$. 
Female Genitalia. Anal tube peach-shaped in dorsal view, apical margin convex and with small angle at middle (Fig. 4C). Paraproct 0.3 times as long as anal tube (Fig. 4C). Gonoplac with disc relatively flat, nearly quadrate in lateral view, apical margin round and with wide membranous part, third gonoplac lobes fused at base, fork strongly sclerotized in dorsal view (Fig. 4A-B). Proximal part of posterior connective lamina of gonapophyses IX slightly protruded, distal part angularly convex near apex, median field divided into two lobes in dorsal view, and morderatly elevated medially in lateral view (Fig. 4D-E). Gonospiculum bridge moderately large, basal part nearly same length as apical part (Fig. 4D). Anterior connective laminae of gonapophysis VIII broad, with three small teeth in apical group and three keeled teeth in lateral group (Fig. 4F). Gonocoxae VIII with hind margin concave (Fig. 4F). Sternite VII with hind margin slightly widely convex at middle part (Fig. 4G).

\section{Gergithus sp.}

Fig. 5A-C

G. signatifrons Melichar, 1906 sensu Baker 1927: 403.

A specimen previously identified as G. signatifrons by Baker (1927) from Siberut Island was examined (BMNH). It differs from the type specimen of $G$. signatifrons by 1) frons with wide blood-red longitudinal fascia medially and green fasciae laterally from upper margin to the line of antennae, lateral green fasciae curved inwards and connected by yellow transverse band, between it and clypeus also blood-red (the latter frons with red longitudinal fascia reaching metopoclypeal suture), lateral area pale yellowish, with black fascia near lateral margin below antennae; 2) clypeus blood-red medially, yellow laterally near metopoclypeal suture, and black-and-red below (the latter clypeus yellow medially and black laterally); 3 ) tegmen fulvous with straw yellow veins (the latter tegmen straw yellow).

All of the above characteristics show Baker's identified specimen to be distinct from G. signatifrons and probably a new species. As the specimen is a female we prefer to wait for males to become available in order to formally describe the species.

\section{Material examined}

INDONESIA: đ, Meita wei, Siberut Island, 2 Oct. 1924, H.H. Karny (BMNH).

Mongoliana Distant, 1909

Fig. 8

Mongoliana Distant, 1909: 87. Type species: Hemisphaerius chilocorides Walker, 1851, by original designation.

\section{Diagnosis}

Coryphe 1.5 times as wide as long, with median carina. Metope slightly longer than wide, a little widened below antenna, with or without a linear series of very small tubercles along lateral margin. Metopoclypeal suture straight. Tegmen widened at basal costal margin, veins inconspicuous, claval suture absent. Hind wing $0.7-0.8$ times length of tegmen, distinctly reticulate in distal part. Anal tube nearly cup-shaped. Pygofer with hind margin convex medially. Aedeagus with pair of ventral processes. Gonostyle with hind margin weakly or distinctly concave, caudo-ventral angle widely rounded.

\section{Distribution}

China, Japan, Indonesia (Sula Islands). 
MENG R. et al., Nomenclatorial changes in the planthopper tribe Hemisphaeriini
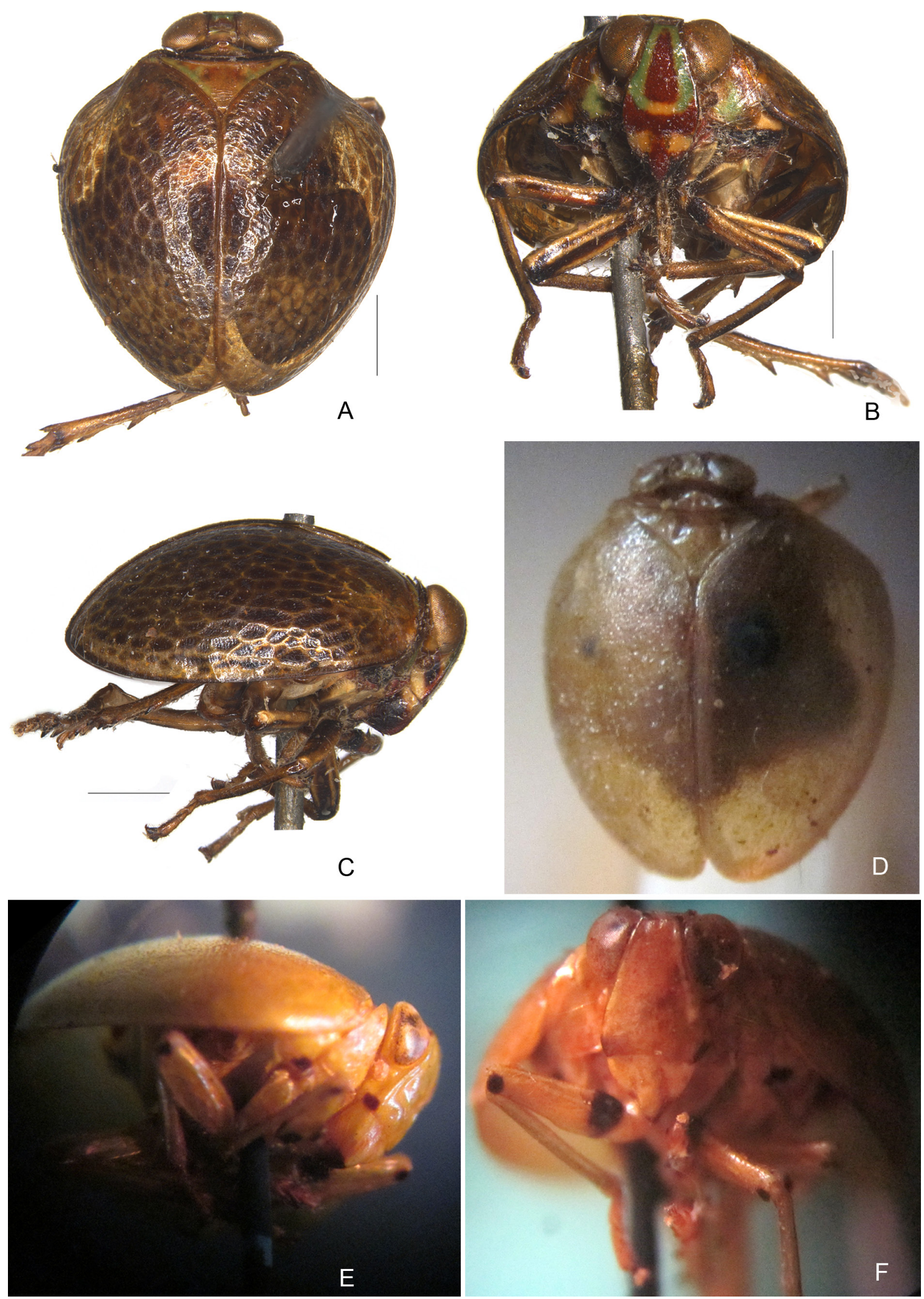

Fig. 5. Gergithus spp. A-C. Gergithus sp. A. Habitus, dorsal view. B. Habitus, frontal view. C. Habitus, lateral view. - D-F. Gergithus cribratus Melichar, 1906. D. Habitus, dorsal view. E. Habitus, lateral view. F. Frons and clypeus, facial view. Scale bars $=1 \mathrm{~mm}$. 

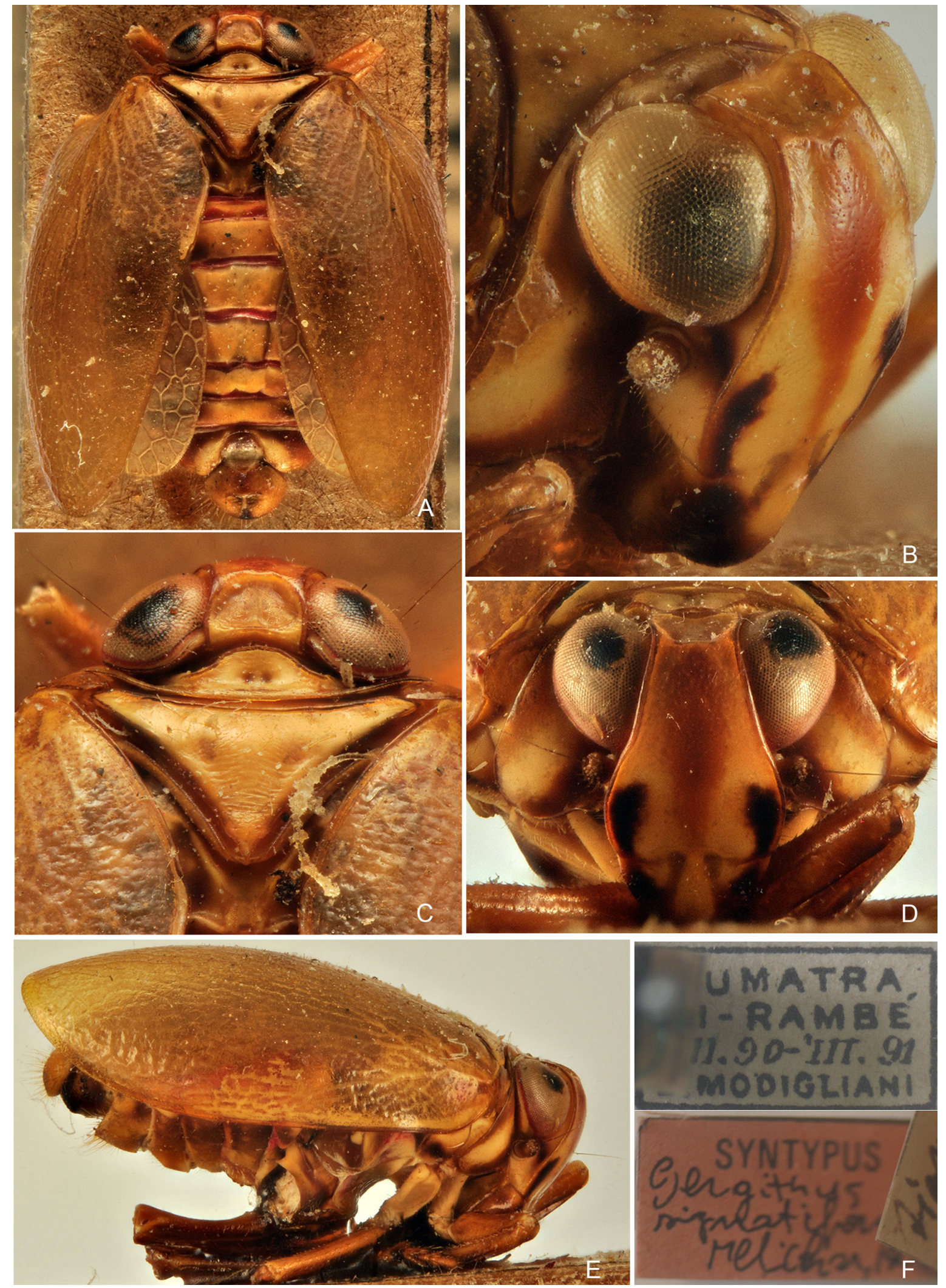

Fig. 6. Gergithus signatifrons Melichar, 1906, syntype. A. Habitus, dorsal view. B. Metope and clypeus, frontolateral view. C. Head and thorax, dorsal view. D. Metope and clypeus, facial view. E. Habitus, lateral view. F. Labels. 

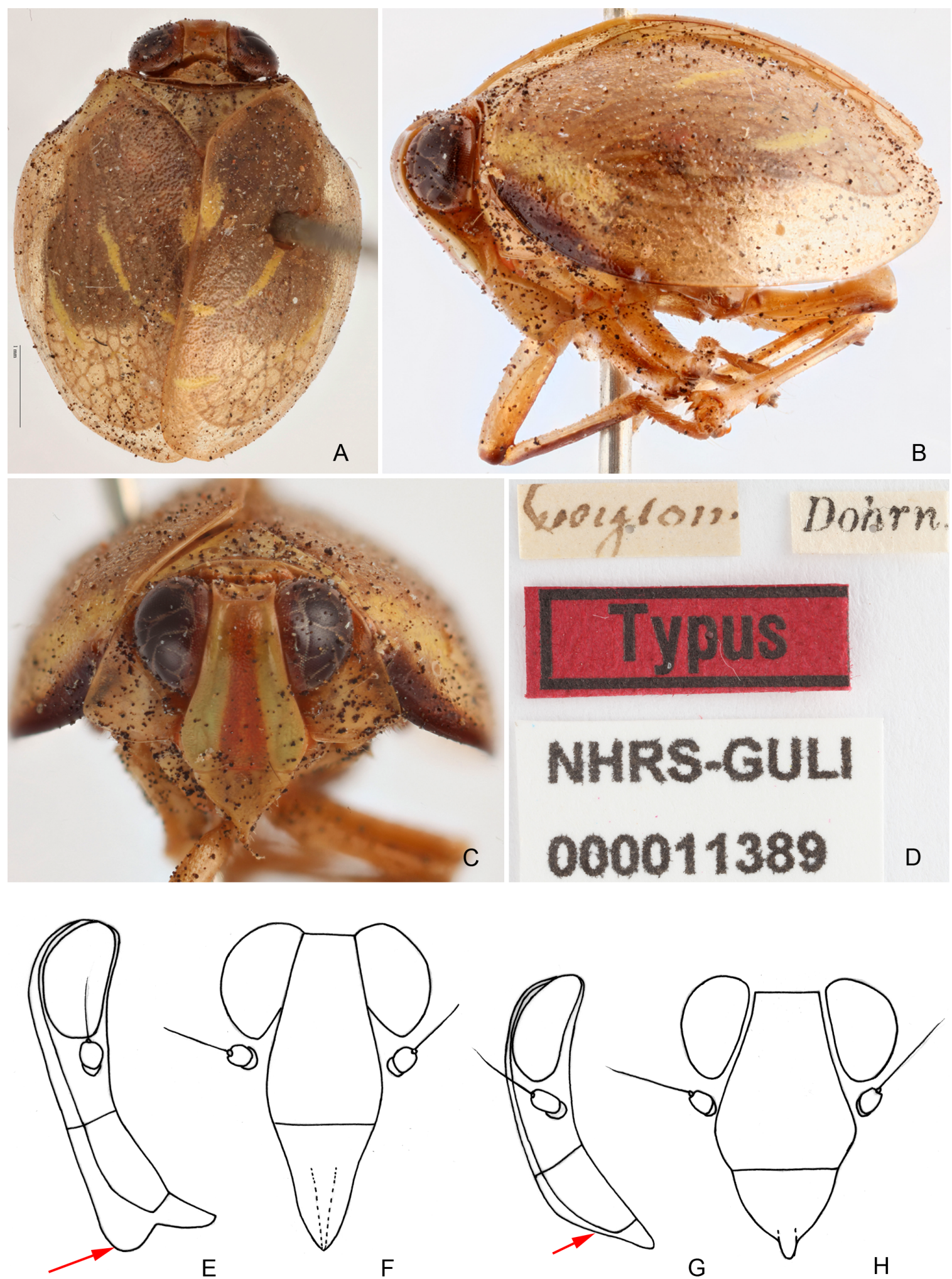



$\mathrm{F}$

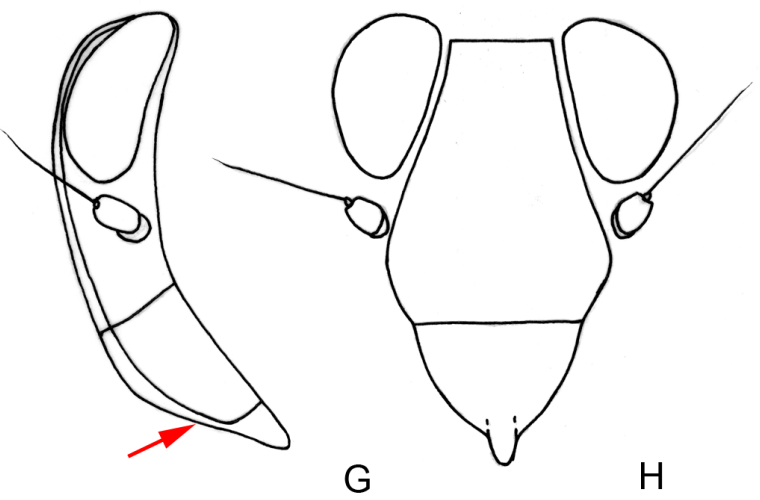

Fig. 7. Hemisphaerini. A-D. Gergithus schaumi (Stål, 1855), syntype. A. Habitus, dorsal view. B. Habitus, lateral view. C. Metope and clypeus, facial view. D. Label. - E-F. Gergithus frontilongus sp. nov. E. Metope and clypeus, lateral view. F. Metope and clypeus, facial view. - G-H. Gnezdilovius iguchii (Matsumura, 1916) comb. nov. G. Metope and clypeus, lateral view. H. Metope and clypeus, facial view. Arrows points the anteclypeus angular or compressed. 


\section{Remarks}

Fourteen species are included in Mongoliana, of which nine were examined in NWAFU. Type specimens of H. chilocorides (BMNH(E) 1705797) and H. recurrens (BMNH(E) 1705798) were also examined and their images are provided here. Although no material of Hemisphaerius contusus is available for study and the type could not be found in BMNH, the species is transferred to Mongoliana based on its original description which states: "front darker along each side is adorned with a row of little yellow tubercles" and "fore-wings widened on the border at the base near which they are slightly concave".

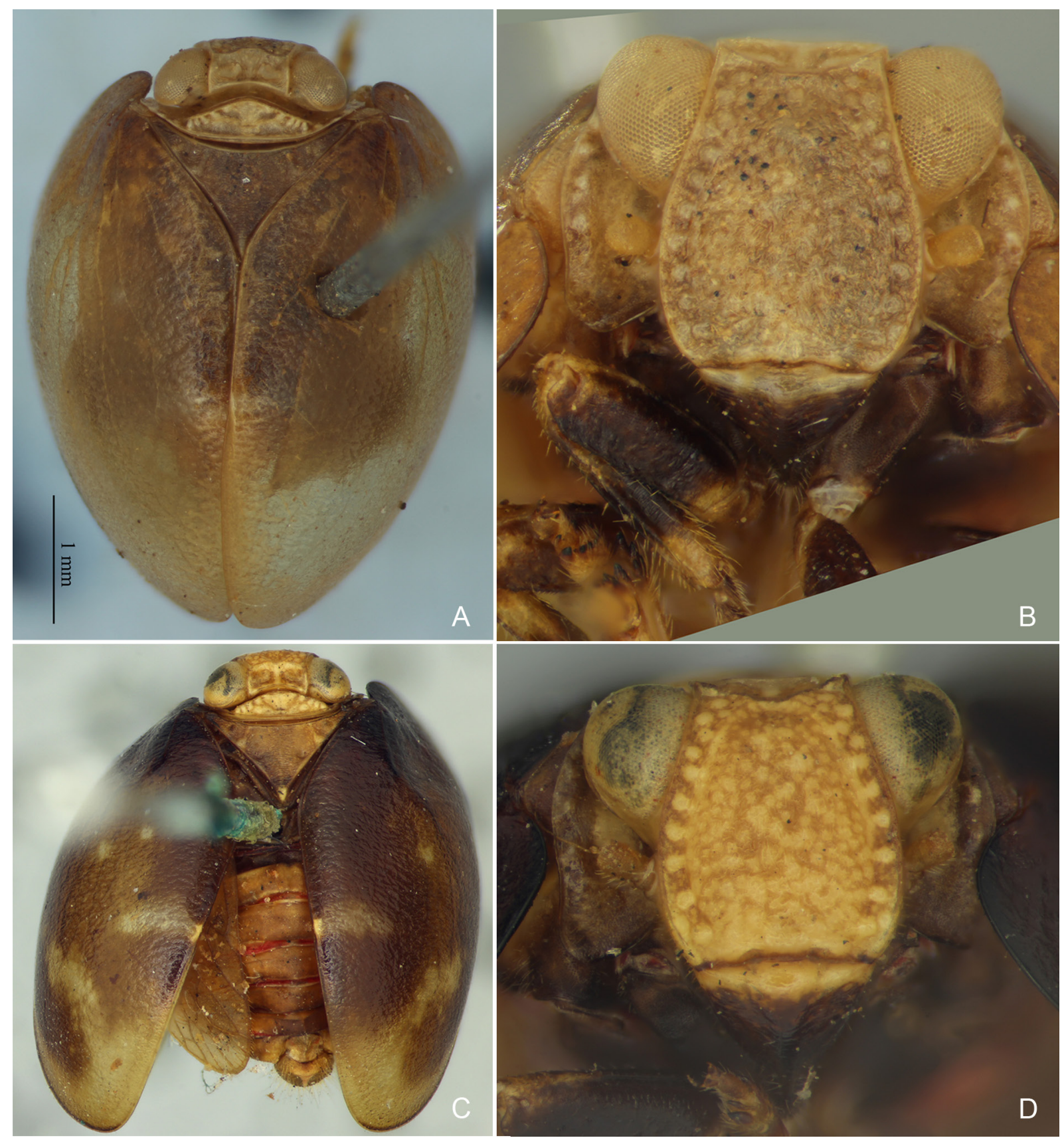

Fig. 8. Mongoliana spp. A-B. Mongoliana chilocorides (Walker, 1851), holotype. A. Habitus, dorsal view. B. Frons and clypeus, facial view. - C-D. Mongoliana recurrens (Butler, 1875), holotype. C. Habitus, dorsal view. D. Frons and clypeus, facial view. 
MENG R. et al., Nomenclatorial changes in the planthopper tribe Hemisphaeriini

Similarly, the specimen of this species recorded by Butler (1875) from Sula Islands could also not be found in BMNH, where other Butler specimens are deposited.

\section{Checklist of species of Mongoliana Distant, 1909}

Specimens deposited in NWAFU indicated by **:

** M. albimaculata Meng, Wang \& Qin, 2016. Meng, Wang \& Qin 2016: 107, figs 21-23, 45-50, China (Guizhou)

M. arcuata Meng, Wang \& Qin, 2016. Meng, Wang \& Qin 2016: 109, China (Yunnan); Chen et al. 2014: 76, fig. 2-31

** M. bistriata Meng, Wang \& Qin, 2016. Meng, Wang \& Qin 2016: 103, figs 1-3, 7-20, China (Guizhou)

M. chilocorides (Walker, 1851). As Hemisphaerius chilocorides Walker, 1851: 379, China (type locality, Hongkong), Japan; Fennah 1956: 504; Chen et al. 2014: 69, fig. 2-27 (Fig. 8A-B)

M. contusus (Walker, 1851) comb. nov. As Hemisphaerius contusus Walker, 1851: 378; Butler 1875:

95, plate IV, fig. 11, China

** M. lanceolata Che, Wang \& Chou, 2003. Che, Wang \& Chou 2003: 36, fig. 1, China (Guangxi); Meng et al. 2016: figs 71-72

** M. latistriata Meng, Wang \& Qin, 2016. Meng, Wang \& Qin 2016: 106, figs 4-6, 27-44, China (Hunan)

** M. naevia Che, Wang \& Chou, 2003. Che, Wang \& Chou 2003: 38, fig. 3, China (Yunnan); Meng et al. 2016: figs $64-65$

** M. pianmaensis Chen, Zhang \& Chang, 2014. Chen, Zhang \& Chang 2014: 71, fig. 2-28, China (Yunnan)

M. qiana Chen, Zhang \& Chang, 2014. Chen, Zhang \& Chang 2014: 73, fig. 2-29, China (Guizhou) M. recurrens (Butler, 1875). As Hemisphaerius recurrens Butler, 1875: 98, plate IV, fig. 20, China (Fujian); Fennah 1956: 504, figs 17G-H, 18A-C, 19B; Chen et al. 2014: 73, fig. 2-30; figs 55-63, 66-70 (Fig. 8C-D)

** M. serrata Che, Wang \& Chou, 2003. Che, Wang \& Chou 2003: 41, fig. 5, China (Guangxi); Meng et al. 2016: figs 42-44

** M. sinuata Che, Wang \& Chou, 2003. Che, Wang \& Chou 2003: 40, fig. 4, China (Yunnan); Meng et al. 2016: figs $77-80$

** M. triangularis Che, Wang \& Chou, 2003. Che, Wang \& Chou 2003: 38, fig. 2, China (Yunnan); Meng et al. 2016: figs 73-76

\section{Gnezdilovius gen. nov. urn:1sid:zoobank.org:act:75C438A6-C66E-4718-8233-32E6D926FBC1}

Fig. 9

\section{Type species}

Gergithus lineatus Kato, 1933.

\section{Diagnosis}

This new genus is similar to Gergithoides and Hemisphaerius. It differs from the former by the following characters: 1) coryphe nearly quadrangular (in Gergithoides coryphe nearly subtriangular); 2) metope smooth without tubercles or median carina (in Gergithoides metope with a row of tubercles and median carina); 3) genital style with hind margin slightly convex, or nearly straight, or weakly concave in middle (in Gergithoides genital style with hind margin strongly concave in middle). The new genus differs from Hemisphaerius by the following characters: 1 ) body medium-sized, male body length varies from 4.0 to $7.0 \mathrm{~mm}$, most often length range from 5.0 to $6.5 \mathrm{~mm}$ (in Hemisphaerius body small, male body length varies from 3.0 to $4.6 \mathrm{~mm}$ ); 2) hind wing well-developed, longer than half length of tegmen, usually 0.7 



B

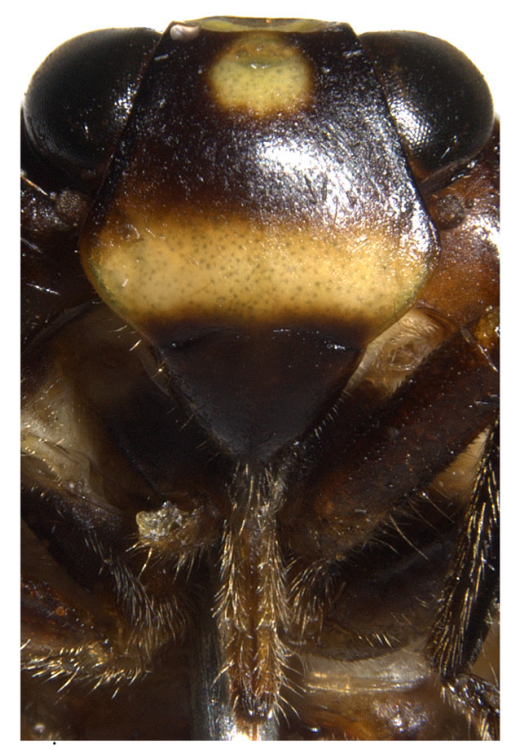

C

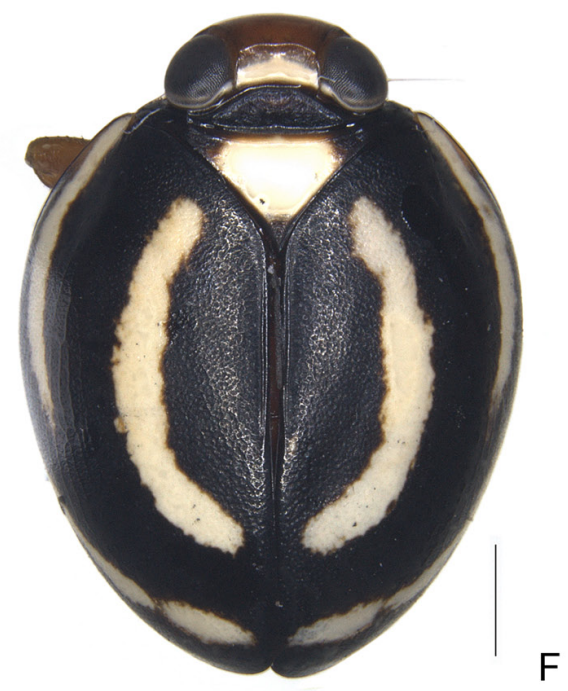

Fig. 9. Gnezdilovius spp. A-C. Gnezdilovius multipunctatus (Che, Zhang \& Wang, 2007) comb. nov., paratype. A. Habitus, dorsal view. B. Habitus, lateral view. C. Metope and clypeus, facial view. - D-F. Gnezdilovius lineatus (Kato, 1933) comb. nov. D. Metope and clypeus, facial view. E. Habitus, lateral view. F. Habitus, dorsal view. Scale bars $=1 \mathrm{~mm}$. 
MENG R. et al., Nomenclatorial changes in the planthopper tribe Hemisphaeriini

times as long as tegmen (in Hemisphaerius hind wing shorter than half length of tegmen, about 0.3 times as long as tegmen); 3) aedeagus usually with variable processes (in Hemisphaerius aedeagus without any process, phallobasal lobes with variable shape).

\section{Etymology}

Named after Dr. Vladimir M. Gnezdilov, who is a great specialist in systematic research of the family Issidae. The name is masculine.

\section{Description}

Head and thorax. Coryphe 2.4 times as wide as long, disc depressed, without carina (Fig. 9A, F). Metope with disc slightly elevated, without median carina, almost as long in midline as at widest point below level of antennae (Fig. 9C-D). Clypeus not angulate, always in same plane as metope (Fig. 9C-D). Rostrum long, reaching metatrochanter. Pronotum slightly longer than coryphe (Fig. 9A, F). Mesonotum smooth, disc slightly elevated. Tegmen elliptical, strongly convex and without claval suture, apical margin usually acutely rounded, longitudinal veins usually weakly prominent or inconspicuous (Fig. 9B, E). Hind wing well-developed, reticulate, more than half length of tegmen. Legs relative long, hind tibia with two lateral spines. Metatibiotarsal formula (6-9)/(8-16)/2.

Male genitalia. Anal tube subtriangular, mushroom-shaped or cup-shaped. Pygofer in lateral view with hind margin roundly or spinously produced caudad. Phallobase with dorsal lobe usually reflexed at apex. Aedeagus with processes. Genital style with caudo-dorsal angle rounded, hind margin slightly convex, or nearly straight, or weakly concave in middle. Capitulum of style short, in caudal view with apical margin obtuse or acute, with small processes, lateral tooth spinule-shaped.

Female genitalia. Sternum VII with middle of posterior margin clearly convex or concave. Anal tube nearly ovate in dorsal view, base wider than apex. Paraproct short. Gonoplac slightly elevated in median area, border between first and second gonoplac lobes obsolete, third gonoplac lobes faintly sclerotized and pigmented. Proximal part of posterior connective lamina of gonapophyses IX convex in lateral view, median field with notch in apical part. Gonocoxa VIII nearly rectangular, dorsal margin slightly protruding in proximal part. Anterior connective lamina of gonapophysis VIII with three teeth in apical group and with two to four carinate teeth in lateral group.

\section{Distribution}

China (Hainan, Yunnan, Guangxi, Guangdong, Hong Kong, Fujian, Taiwan, Zhejiang, Guizhou, Chongqing), Japan, Vietnam.

\section{Remarks}

The new genus can be distinguished by the wide coryphe (more than twice as wide as long), metope almost as long as wide, clypeus small and compressed and hind wing well developed.

Forty species are here transfered to Gnezdilovius gen. nov. from Gergithus, of which we have examined type specimens of 11 species in NWAFU and specimens of several species in BMNH, where paratypes are present of G. chihpensis, G. rosticus and G. pendulus and syntypes of G. flavimaculata. All other species are known to us only by their descriptions and illustrations. Images are provided of G. lineatus (type species) based on specimens collected in Taiwan and deposited in NWAFU (Fig. 9D-F).

\section{Checklist of species of Gnezdilovius gen. nov.}

Specimens deposited in BMNH indicated by * and in NWAFU by **:

* G. affinis (Schumacher, 1915) comb. nov. As Gergithus affinis Schumacher, 1915: 135, China 
(Taiwan); Hori 1969: 55, fig. 2: 12-13, pl. 2 fig. 13; Chan \& Yang 1994: 23, fig. 6

** G. bimaculatus (Zhang \& Che, 2009) comb. nov. As Gergithus bimaculatus Zhang \& Che, 2009: 185, figs 16-27, China (Yunnan); Meng \& Wang 2012: 11, figs 43-64

* G. bistriatus (Schumacher, 1915) comb. nov. As Gergithus bistriatus Schumacher, 1915: 136, China (Taiwan); Chan \& Yang 1994: 31, fig. 11

G. carbonarius (Melichar, 1906) comb. nov. As Gergithus carbonarius Melichar, 906: 65, China (Taiwan), Japan; Chan \& Yang 1994: 29, fig. 90

** G. chelatus (Che, Zhang \& Wang, 2007) comb. nov. As Gergithus chelatus Che, Zhang \& Wang, 2007: 617, figs 24-32, China (Hainan)

* G. chihpensis (Chan \& Yang, 1994) comb. nov. As Gergithus chihpensis Chan \& Yang, 1994: 38, fig. 14, China (Taiwan)

G. flaviguttatus (Hori, 1969) comb. nov. As Gergithus flaviguttatus Hori, 1969: 56, pl. 2: 16, China (Taiwan), Japan

* G. Alavimacula (Walker, 1851) comb. nov. As Hemisphaerius flavimacula Walker, 1851: 378, China (Hong Kong); Butler 1875: 98, pl. IV, fig. 19

* G. formosanus (Metcalf, 1955) comb. nov. As Gergithus formosanus Metcalf, 1955: 263, China (Taiwan), Japan; Chan \& Yang 1994: 38, fig. 15

G. gravidus (Melichar, 1906) comb. nov. As Gergithus gravidus Melichar, 1906: 61, China (Guangxi), Vietnam; Che et al. 2007: 612, figs 1-4; Chen et al. 2014: 52, fig. 2-15A-I

G. horishanus (Matsumura, 1916) comb. nov. As Gergithus horishanus Matsumura, 1916: 102, China (Taiwan); Hori 1969: 56, pl. 2: 12

G. hosticus (Chan \& Yang, 1994) comb. nov. As Gergithus hosticus Chan \& Yang, 1994: 31, fig. 10, China (Taiwan)

G. iguchii (Matsumura, 1916) comb. nov. As Gergithus iguchii Matsumura, 1916: 98, China (Zhejiang, Fujian, Guangdong), Japan, Vietnam; Hori 1969: 60, fig. 2: 1-4, pl. 2 fig. 6; Chen et al. 2014: 52, fig. 2-16A-I

* G. lineatus (Kato, 1933) comb. nov. As Gergithus lineatus Kato, 1933: 461 (type species), China (Taiwan), Japan; Chan \& Yang 1994: 43, fig. 17 (Fig. 9D-F)

G. longulus (Schumacher, 1915) comb. nov. As Gergithus longulus Schumacher, 1915: 135, China (Taiwan), Japan; Hori 1969: 56, pl. 2 fig. 14; Chan \& Yang 1994: 47, fig. 20

G. luteomaculatus (Constant \& Pham, 2016) comb. nov. As Gergithus luteomaculatus Constant \& Pham, 2016: 6, figs 1, 2A-B, 3-4, Vietnam

** G. multipunctatus (Che, Zhang \& Wang, 2007) comb. nov. As Gergithus multipunctatus Che, Zhang \& Wang, 2007: 621, China (Hainan); Constant \& Pham 2016: 9, figs 1, 2C-D (Fig. 9A-C)

* G. nigrolimbatus (Schumacher, 1915) comb. nov. As Gergithus nigrolimbatus Schumacher, 1915: 134, China (Taiwan); Chan \& Yang 1994: 45, fig. 18

** G. nonomaculatus (Meng \& Wang, 2012) comb. nov. As Gergithus nonomaculatus Meng \& Wang, 2012: 5, figs 1-5, China (Hainan); Constant \& Pham 2016: 10, figs 2E-F (Figs 1, 2E-F)

* G. nummarius (Chan \& Yang, 1994) comb. nov. As Gergithus nummarius Chan \& Yang, 1994: 23, fig. 7, China (Taiwan)

G. okinawanus (Matsumura, 1936) comb. nov. As Gergithus okinawanus Matsumura, 1936: 82, Japan; Hori 1969: 55, fig. 1: 1-3, pl. 2 fig. 10

** G. parallelus (Che, Zhang \& Wang, 2007) comb. nov. As Gergithus parallelus Che, Zhang \& Wang, 2007: 619, figs 33-41, China (Hainan)

* G. pendulus (Chan \& Yang, 1994) comb. nov. As Gergithus pendulus Chan \& Yang, 1994: 47, fig. 7, China (Taiwan)

** G. pseudotessellatus (Che, Zhang \& Wang, 2007) comb. nov. As Gergithus pseudotessellatus Che, Zhang \& Wang, 2007: 623, figs 51-59, China (Hainan); Chen et al. 2014: 55, fig. 2-18A-I

** G. quinquemaculatus (Che, Zhang \& Wang, 2007) comb. nov. As Gergithus quinquemaculatus Che, 
MENG R. et al., Nomenclatorial changes in the planthopper tribe Hemisphaeriini

Zhang \& Wang, 2007: 615, figs 5-13, China (Guangxi, Guizhou); Chen et al. 2014: 58, fig. 2-19A-I

G. robustus (Schumacher, 1915) comb. nov. As Gergithus robustus Schumecher, 1915: 127, China (Taiwan); Hori 1969: 56, pl. 2 fig. 15; Chan \& Yang 1994: 50, fig. 21

* G. rosticus (Chan \& Yang, 1994) comb. nov. As Gergithus rosticus Chan \& Yang, 1994: 34, fig. 12, China (Taiwan)

G. rotundus (Chan \& Yang, 1994) comb. nov. As Gergithus rotundus Chan \& Yang, 1994: 36, fig. 12, China (Taiwan)

** G. rugiformis (Zhang \& Che, 2009) comb. nov. As Gergithus rugiformis Zhang \& Che, 2009: 183, figs 1-15, China (Chongqing, Guangxi)

G. satsumensis (Matsumura, 1916) comb. nov. As Gergithus satsumensis Matsumura, 1916: 101, Japan; Hori 1969: 52, fig. 1: 4-6, pl. 2 figs 5-8

** G. spinosus (Che, Zhang \& Wang, 2007) comb. nov. As Gergithus spinosus Che, Zhang \& Wang, 2007: 615, figs 14-23, China (Hainan)

G. stramineus (Hori, 1969) comb. nov. As Gergithus stramineus Hori, 1969: 58, pl 3 fig. 3, China (Taiwan)

G. taiwanensis (Hori, 1969) comb. nov. As Gergithus taiwanensis Hori, 1969: 54, fig. 1: 7-9, pl. 2 fig. 9, China (Taiwan)

G. tamdao (Constant \& Pham, 2016) comb. nov. As Gergithus tamdao Constant \& Pham, 2016: 11, figs $1,2 \mathrm{G}-\mathrm{H}, 5-6$, Vietnam

G. tessellatus (Matsumura, 1916) comb. nov. As Gergithus tessellatus Matsumura, 1916: 102,China (Zhejiang, Fujian, Taiwan), Japan; Chan \& Yang 1994: 50, fig. 21; Meng \& Wang 2012: 11, figs 65-73; Chen et al. 2014: 60, fig. 2-20A-I

** G. tristriatus (Meng \& Wang, 2012) comb. nov. As Gergithus tristriatus Meng \& Wang, 2012: 8, figs 19-38, 40, 42, China (Yunnan)

* G. unicolor (Melichar, 1906) comb. nov. As Gergithus unicolor Melichar, 1906: 66, China (Taiwan); Chan \& Yang 1994: 27, fig. 8

G. variabilis (Butler, 1875) comb. nov. As Hemisphaerius variabilis Butler, 1875: 98, 99, pl. IV, fig. 21, China (Hong Kong)

* G. yayeyamensis (Hori, 1969) comb. nov. As Gergithus yayeyamensis Hori, 1969: 55, fig. 1: 10-11, pl. 2 fig. 11, China (Taiwan, Japan)

** G. yunnanensis (Che, Zhang \& Wang, 2007) comb. nov. As Gergithus yunnanensis Che, Zhang \& Wang, 2007: 625, figs 60-67, China (Yunnan)

Hemisphaeroides Melichar, 1903

Figs 10-11

Hemisphaeroides Melichar, 1903: 75. Type species: Hemisphaeroides aeneoniger Melichar, 1903, by original designation.

\section{Diagnosis}

Body semicircular, smooth. Head including eyes wider than pronotum. Coryphe wide, 4.5 times as wide as long. Metope passing smoothly onto coryphe, greatly expanded laterally below antennae. Clypeus broadly triangular, placed horizontally and at right angle to surface of metope. Pronotum short, slightly longer than coryphe. Mesonotum large, triangularly convex. Tegmen semicircular, strongly convex, basal costal margin slightly protruding anteriorly. Hind wing with single lobe, slightly shorter than tegmen. Hind tibiae with two spines.

\section{Distribution}

Sri Lanka. 


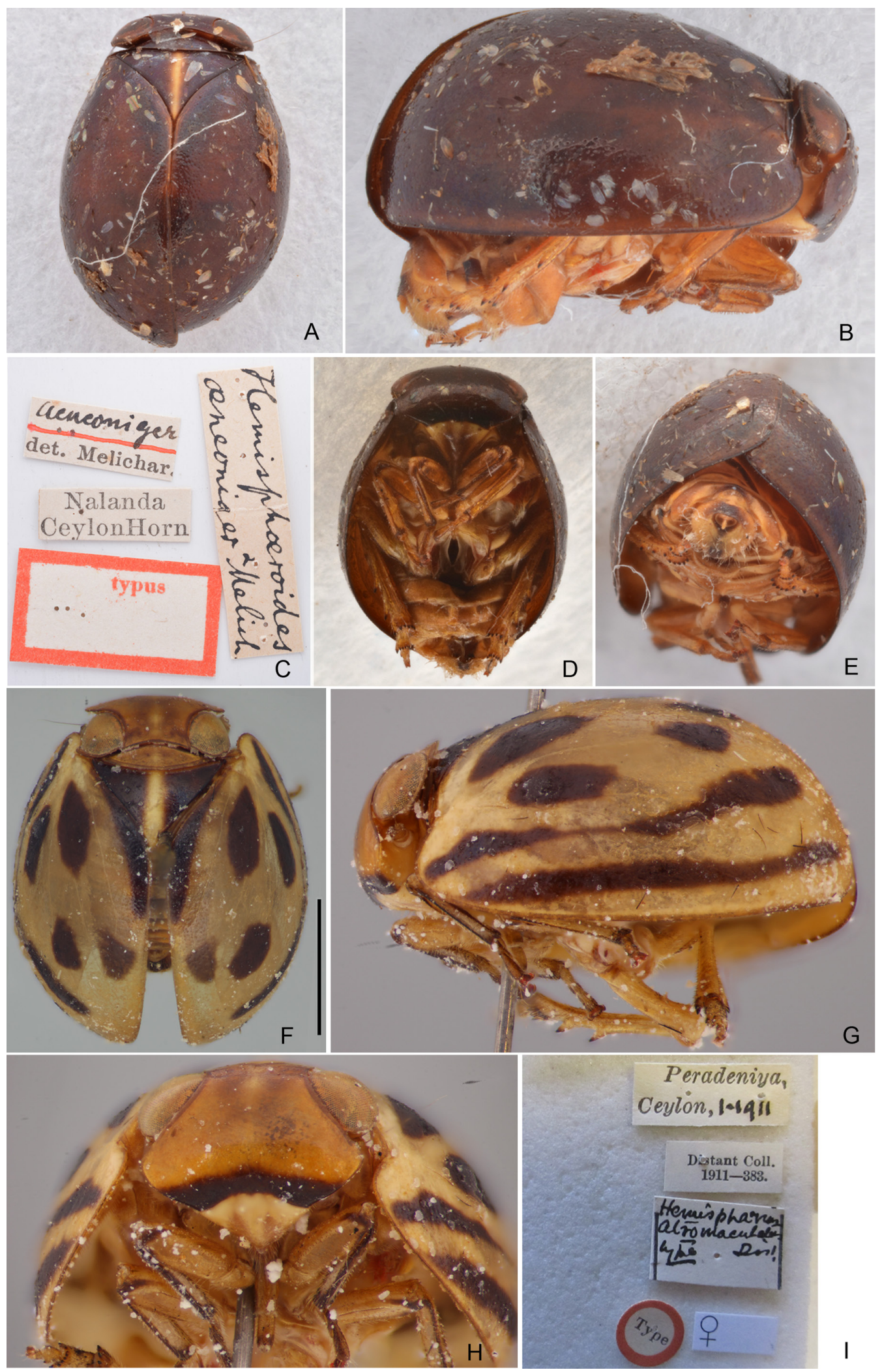

Fig. 10. Hemisphaeroides spp. A-E. Hemisphaeroides aeneoniger Melichar, 1903, syntype. A. Habitus, dorsal view. B. Habitus, lateral view. C. Labels. D. Habitus, ventral view. E. Habitus, caudal view. F-I. Hemisphaeroides atromaculatus Distant, 1916, syntype. F. Habitus, dorsal view. G. Habitus, lateral view. H. Metope and clypeus, facial view. I. Labels. Scale bar $=1 \mathrm{~mm}$. 
MENG R. et al., Nomenclatorial changes in the planthopper tribe Hemisphaeriini

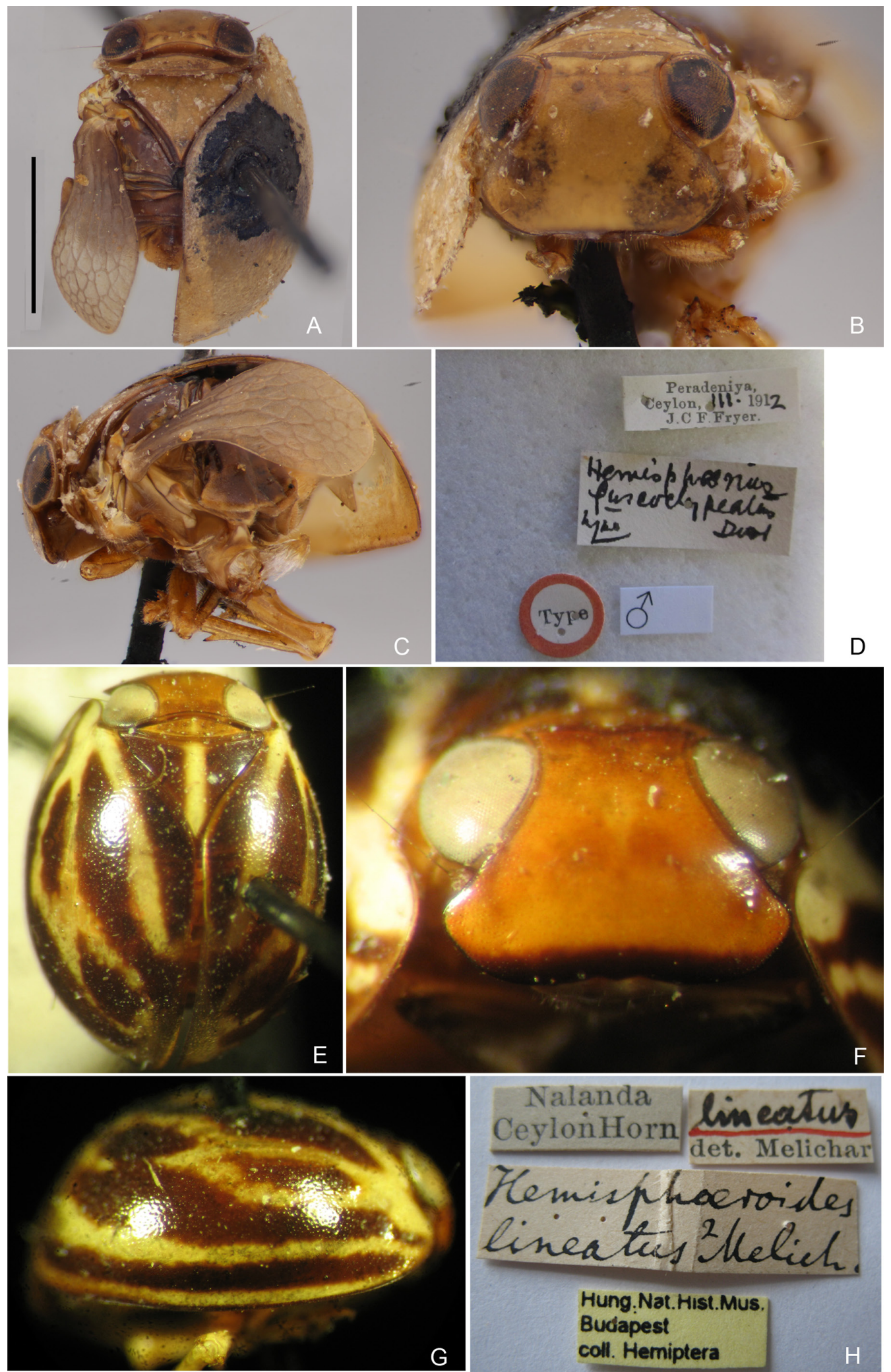

Fig. 11. Hemisphaeroides spp. A-D. Hemisphaeroides fuscoclypeatus Distant, 1916, holotype. A. Habitus, dorsal view. B. Metope and clypeus, facial view. C. Habitus, lateral view. D. Labels. E-H. Hemisphaeroides lineatus Melichar, 1903, syntype. E. Habitus, dorsal view. F. Metope and clypeus, facial view. G. Habitus, lateral view. H. Labels. Scale bar $=1 \mathrm{~mm}$. 


\section{Checklist of species of Hemisphaeroides Melichar, 1903}

H. aeneoniger Melichar, 1903. Melichar 1903: 75 (type species), Sri Lanka; Distant 1906: 364, fig. 188 (Fig. 10A-E)

H. atromaculatus Distant, 1916 comb. nov. As Hemisphaerius atromaculatus Distant, 1916: 105, Sri Lanka (Fig. 10F-I)

H. fuscoclypeatus Distant, 1916 comb. nov. As Hemisphaerius fuscoclypeatus Distant 1916: 105, Sri Lanka (Fig. 11A-D)

H. lineatus Melichar, 1903. Melichar 1903: 76, Sri Lanka (Fig. 11E-H)

\section{Remarks}

Hemisphaeroides aeneoniger and $H$. lineatus are known to us from images of their type specimens (HNHM) provided here. Images of the type specimens examined of $H$. atromaculatus $(\mathrm{BMNH}(\mathrm{E})$ 1705790) and H. fuscoclypeatus (BMNH(E) 1705791) are also provided here.

\section{Discussion}

Most genera in the tribe Hemisphaeriini, including Gnezdilovius gen. nov., have the coryphe transverse and relatively wide (Fig. 7F) and the metope also relatively wide (Fig. 10D). Exceptions are the genera Neogergithoides (Fig. 1C), Macrodaruma (Fig. 1A) and Choutagus (Fig. 1E), where the coryphe and metope are longer than wide, and Gergithus, where the coryphe is nearly quadrate (Fig. 6A) and the metope very elongate (Fig. 6C). Gergithus also differs from all other Hemisphaeriini by the angular anteclypeus in lateral view (Fig. 6B). In addition, although G. iguchii and G. quinquemaculatus (see Che et al. 2007: figs 5-6; Chen et al. 2014: fig. 2-19A-E) have the metope slightly longer than wide and therefore fall between Gergithus and Gnezdilovius gen. nov., they do not have the angular anteclypeus found in Gergithus. On this basis, these two species are transferred to Gnezdilovius gen. nov.

The genera Gergithus and Gnezdilovius gen. nov. are both widely distributed in the Oriental region. Compared to Gergithus, which is found mainly on the Indian subcontinent and also SE Asia (Thailand, Burma, Indonesia), Gnezdilovius gen. nov. is found mainly in southern China and also SE Asia (Vietnam) and the Palaearctic region (Japan) (see Checklists). Additionally, the genus Hemisphaeroides seems to be limited in its distribution to Sri Lanka. Mongoliana is mainly distributed in southern China.

Data on the ecology of Hemisphaeriini are meagre. It has been observed that the unnamed host plant of Hemisphaerius lysanias Fennah, 1978 withered when fed on in open areas in Hainan Island of China (Y.-L. Che, pers. comm. 2003). Both Hemisphaerius cattiensis Constant \& Pham, 2011 and H. hippocrepis Constant \& Pham, 2011 were collected in a forest (Constant \& Pham 2011); H. hippocrepis occurs on forest undergrowth and forest roadsides in Vietnam (Gnezdilov 2013b), while H. interclusus was usually collected in open sunlit areas, particularly along roads and in glades, on the plant Saccharum spontaneum (L.) (Poaceae) (Gnezdilov 2013b); Rotundiforma nigrimaculata Meng, Wang \& Qin, 2013 was collected in China on bamboos (Gigantochloa ligulata Gamble and Dendrocalamus sp.) by canopy fogging (Meng et al. 2013). The new species Gergithus frontilongus sp. nov. was also collected by forest canopy fogging (Zheng \& Li 2013).

\section{Acknowledgements}

We are sincerely grateful to Prof. Shuqiang Li (Institute of Zoology, Chinese Academy of Sciences) for providing specimens. We are also sincerely grateful to Prof. Andrea Lucchi, Prof. Elisabetta Rossi, Riccardo Antonelli (Department of Agriculture, Food and Environment, University of Pisa, Italy), Dr Roberto Poggi and Dr Ssa Tavano (MSNG), Gunvi Lindberg (NHRS), Mária Tóth and Orosz András (HNHM) and Dr Vladimir Gnezdilov (Russian Academy of Sciences, St. Petersburg, Russia) for their help in obtaining images of type specimens. We especially thank Dr Gnezdilov for his comments on the 
MENG R. et al., Nomenclatorial changes in the planthopper tribe Hemisphaeriini

manuscript. This study is supported by the National Natural Science Foundation of China (31372234, 30970388, 31420103911), and Fauna Sinica (2006FY120100) under the Ministry of Science and Technology of China.

\section{References}

Baker C.F. 1927. Spolia Mentawiensia: Homoptera-Fulgoroidea. Philippine Journal of Science 32: 391-411.

Bourgoin T., Wang R.-R., Asche M., Hoch H., Soulier-Perkins A., Stroiński A., Yap S. \& Szwedo J. 2014. From micropterism to hyperpterism: recognition strategy and standardized homology-driven terminology of the forewing venation patterns in planthoppers (Hemiptera: Fulgoromorpha). Zoomorphology 134: 63-77. https://doi.org/10.1007/s00435-014-0243-6

Butler A.G. 1875. List of the species of the homopterous genus Hemisphcrius, with descriptions of new forms in the collection of the British Museum. Annals and Magazine of Natural History 16: 92-100. Available from http://biodiversitylibrary.org/page/25127974 [accessed 17 Feb. 2017].

Chan M.-L. \& Yang C.-T. 1994. Issidae of Taiwan (Homoptera: Fulgoroidea). Chen Chung Book Press, Taichung.

Che Y.-L., Wang Y.-L. \& Chou I. 2003. Taxonomic study of the genus Mongoliana Distant (Homoptera: Fulgoroidea: Issidae). Entomotaxonomia 25: 35-44.

Che Y.-L., Zhang Y.-L. \& Wang Y.-L. 2007. Seven new species and one new record of Gergithus Stål (Hemiptera: Fulgoroidea: Issidae) from China. Proceedings of the Entomological Society of Washington 109: 611-627.

Chen X.-S., Zhang Z.-G. \& Chang Z.-M. 2014. Issidae and Caliscelidae (Hemiptera: Fulgoroidea) from China. Guizhou Science and Technology Publishing House, Guiyang.

Constant J. \& Pham H.-T. 2011. Two new species of Hemisphaerius from Vietnam (Hemiptera, Fulgoromorpha, Issidae). Nouvelle Revue d'Entomologie (Nouvelle Série) 27: 109-115.

Constant J. \& Pham H.-T. 2016. Maculergithus, a new subgenus in Gergithus Schumacher, 1915 with two new species from northern Vietnam (Hemiptera: Fulgoromorpha: Issidae). European Journal of Taxonomy 198: 1-16. https://doi.org/10.5852/ejt.2016.198

Distant W.L. 1906. The Fauna of British India including Ceylon and Burma. Rhynchota 3 (Heteroptera Homoptera). Taylor and Francis, London.

Distant W.L. 1916. The Fauna of British India including Ceylon and Burma. Rhynchotal 6, Homoptera: Appendix. Taylor and Francis, London.

Fennah R.G. 1956. Fulgoroidea from Southern China. Proceedings of the California Academy of Sciences 28: 441-527.

Fennah R.G. 1967. New and little known Fulgoroidea from South Africa (Homoptera). Annals of the Natal Museum 18: 655-714.

Fennah R.G. 1978. Fulgoroidea (Homoptera) from Vietnam. Annales Zoologici Warszawa 34: 63-267.

Gnezdilov V.M. 2003. Review of the family Issidae (Homoptera, Cicadina) of the European fauna, with notes on the structure of the ovipositor of planthoppers. Chteniya pamyati N. A. Kholodkovskogo [Meetings in Memory of N.A. Cholodkovsky], St. Petersburg 56: 1-145.

Gnezdilov V.M. 2009. Revisionary notes on some tropical Issidae and Nogodinidae (Hemiptera: Fulgoroidea). Acta Entomologica Musei Nationalis Pragae 49: 75-92. 
Gnezdilov V.M. 2013a. "Issidisation" of fulgoroid planthoppers (Homoptera, Fulgoroidea) as a case of parallel adaptive radiation. Entomologicheskoe Obozrenie 92: 62-69. [English translation published in Entomological Review 93: 825-830.]

Gnezdilov V.M. 2013b. Notes on planthoppers of the tribe Hemisphaeriini (Homoptera, Fulgoroidea, Issidae) from Vietnam with a description of a new genus and a new species. Zoologicheskii Zhurnal 92: 659-663. [English translation published in Entomological Review 93: 1024-1028.]

Gnezdilov V.M. 2013c. Modern classification and distribution of the family Issidae Spinola (Homoptera, Auchenorrhyncha: Fulgoroidea). Entomologicheskoe Obozrenie 92: 724-738. [English translation published in Entomological Review 94: 687-697.]

Gnezdilov V.M. 2015. New genus and new species of the tribe Hemisphaeriini (Hemiptera: Fulgoroidea: Issidae) from Brunei. Acta Entomologica Musei Nationalis Pragae 55: 9-18.

Gnezdilov V.M., Holzinger W.E. \& Wilson M.R. 2014b. The Western Palaearctic Issidae (Hemiptera, Fulgoroidea): an illustrated checklist and key to genera and subgenera. Proceedings of the Zoological Institute RAS 318 (Supplement 1): 1-124.

Hori Y. 1969. Hemisphaeriinae of the Japan Archipelago (Hemiptera: Issidae). Transactions of the Shikoku Entomological Society 10: 49-64.

Kato M. 1933. Notes on Japanese Homoptera, with descriptions of one new genus and some new species. The Entomological World, Organ of the Insect Lover's Association 1: 452-471.

Kirby W. F. 1891. Catalogue of the described Hemiptera Heteroptera and Homoptera of Ceylon, based on the collection formed by Mr. E. Ernest Green. Zoological Journal of the Linnean Society 24: 72-176.

Liang A.-P. 2001. Taxonomic notes on Oriental and Eastern Palaearctic Fulgoroidea (Hemiptera). Journal of the Kansas Entomological Society 73: 235-237.

Matsumura S. 1916. Synopsis der Issiden (Fulgoriden) Japans. Transactions of the Shikoku Entomological Society 6: 85-118.

Matsumura S. 1936. Six new species of Homoptera collected at Okinawa by Mr. Chiro Yohene. Insecta Matsumurana 10: 81-84.

Melichar L. 1903. Homopteren-Fauna von Ceylon. Verlag von Felix L. Dames, Berlin.

Melichar D.L. 1906. Monographie der Issiden (Homoptera). Abhandlungen der kaiserlich königlichen Zoologisch- botanischen Gesellschaft in Wien 3: 1-327.

Meng R. \& Wang Y.-L. 2012. Two new species of the genus Gergithus Stål (Hemiptera: Fulgoromorpha: Issidae) from China, with a redescription of $G$. bimaculatus Zhang and Che, and G. tessellatus Matsumura. Zootaxa 3247: 1-18.

Meng R., Wang Y.-L. \& Qin D.-Z. 2013. A new genus of the tribe Hemisphaeriini (Hemiptera: Fulgoromorpha: Issidae) from China. Zootaxa 3691:283-290. https://doi.org/10.11646/zootaxa.3691.2.7

Meng R., Wang Y.-L. \& Qin D.-Z. 2016. Four new species in the genus Mongoliana Distant (Hemiptera: Fulgoromorpha: Issidae) from Southern China. Zootaxa 4061: 101-118. https://doi.org/10.11646/ zootaxa.4061.2.1

Metcalf Z.P. 1952. New names in the Homoptera. Journal of the Washington Academy of Sciences 42: $226-231$.

Metcalf Z. P. 1955. New names in Homoptera. Journal of the Washington Academy of Sciences 45: $262-267$. 
MENG R. et al., Nomenclatorial changes in the planthopper tribe Hemisphaeriini

Metcalf Z.P. 1958. General Catalogue of the Homoptera, Fascicle IV Fulgoroidea, Part 15 Issidae. North Carolina State College, Raleigh.

Rahman M.A., Kwon Y.J. \& Suh S.J. 2012. A new species of the genus Gergithoides Schumacher (Hemiptera: Fulgoroidea: Issidae) from Korea. Entomological News 122: 293-299. https://doi. org $/ 10.3157 / 021.122 .0401$

Schumacher F. 1915. Homoptera in H. Sauter's Formosa-Ausbeute. Supplementa Entomologica 4: 108142.

Stål C. 1855. Nya Hemiptera. Ofversigt af Kongliga Svenska Vetenskaps-Akademiens Förhandlingar 12: 181-192.

Stål C. 1870. Hemiptera insularum Philippinarum. Bidrag till Philippinska öarnes Hemipter-fauna. Öfversigt af Kongliga Svenska Vetenskaps-Akademiens Förhandlingar 27: 607-776.

Walker F. 1851. List of the Specimens of Homopterous Insects in the Collections of the British Museum. Part II. British Museum, London.

Walker F. 1857. Catalogue of the Homopterous insects collected at Sarawak, Borneo, by Mr A.R. Wallace, with descriptions of new species. Journal and Proceedings of the Linnaean Society 1: 141-175.

Walker F. 1858. Supplement. List of the specimens of Homopterous insects in the collection of the British Museum. British Museum (Natural History), London.

Walker F. 1862. Characters of undescribed species of Homoptera in the collection of F.P. Pascoe, F.L.S. Journal of Entomology 1: 303-319.

Zhang Y.-L., Wang Y.-L. \& Che Y.-L. 2006. A new genus of the subfamily Hemisphaeriinae (Hemiptera: Fulgoroidea: Issidae) from China. Proceedings of the Entomological Society of Washington 108: 165168.

Zhang Y. \& Che Y.-L. 2009. Checklist of Gergithus Stål (Hemiptera: Issidae; Hemisphaeriinae) with descriptions of two new species from China. Entomotaxonomia 31: 181-187.

Zheng G. \& Li S.-Q. 2013. The biodiversity of arthropods from forest canopies. Acta Zootaxonomica Sinica 38: 178-182.

Manuscript received: 4 March 2016

Manuscript accepted: 1 August 2016

Published on: 14 March 2017

Topic editor: Gavin Broad

Desk editor: Jeroen Venderickx and Kristiaan Hoedemakers

Printed versions of all papers are also deposited in the libraries of the institutes that are members of the EJT consortium: Muséum national d'Histoire naturelle, Paris, France; Botanic Garden Meise, Belgium; Royal Museum for Central Africa, Tervuren, Belgium; Natural History Museum, London, United Kingdom; Royal Belgian Institute of Natural Sciences, Brussels, Belgium; Natural History Museum of Denmark, Copenhagen, Denmark; Naturalis Biodiversity Center, Leiden, the Netherlands. 